تثبيت يتاسيم و ارتباط آن با خصوصيات فيزيكى، شيميايى و كانىهاى رسى

خاكهاى آهكى دشت كاكان، استان كهخيلويه و بويراحمد

\author{
سيروس شاكرى 1*

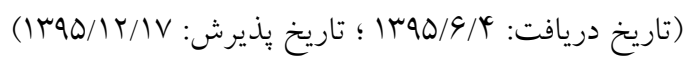

جكيده

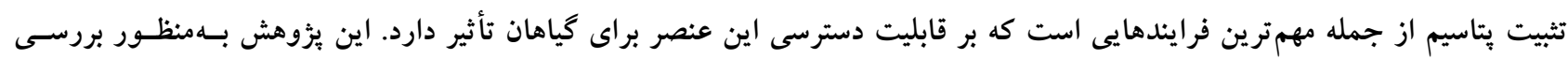

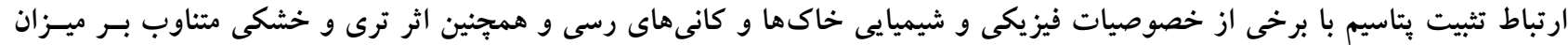

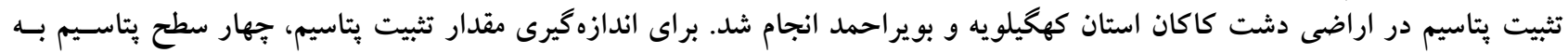

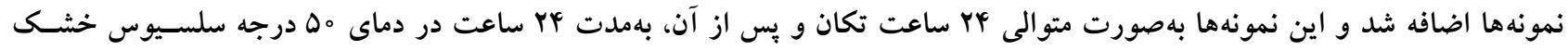

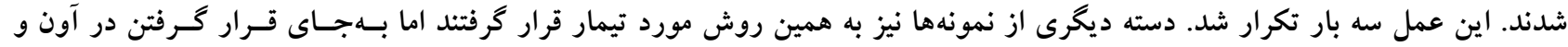

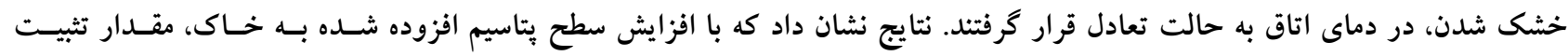

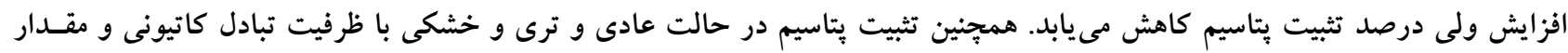

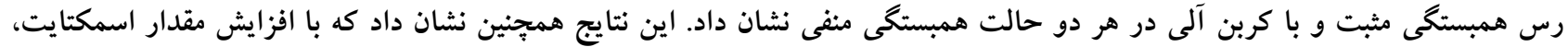

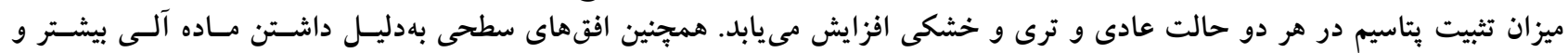
اسمكتايت كمتر، مقدار كمترى بتاسيم تثبيت كردند.

وازههاى كليدى: اسمكتايت، تثبيت بِتاسيم، ترى و خشكى، دشت كاكان، كربن آلى 


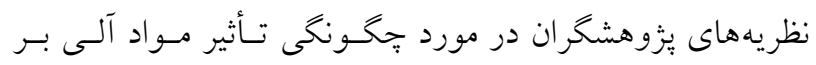

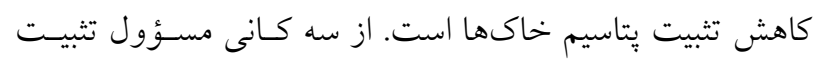

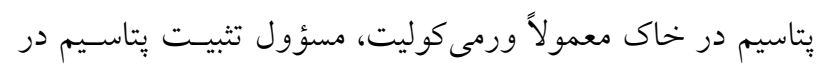

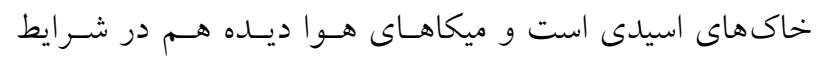

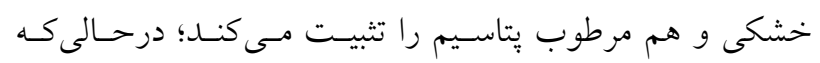

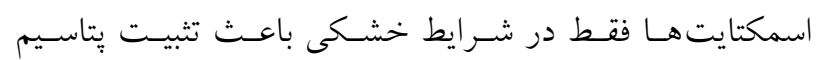

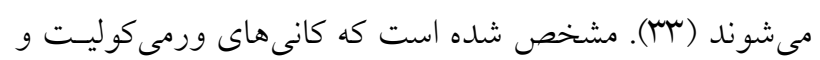

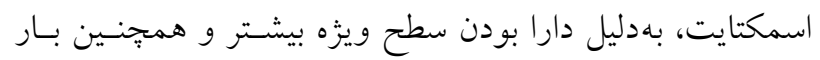

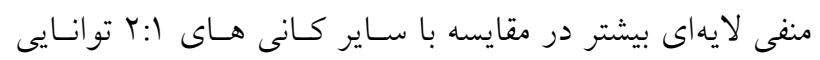
تثبيت پِتاسيم بيشترى را دارند (N). يزووهشكر ان زيادى ارتباط بـين دهيدراتاسـيون فضـاهاى بـين

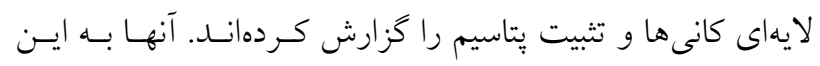

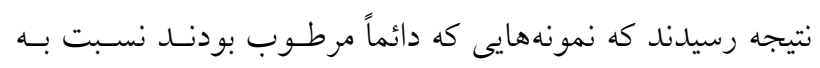

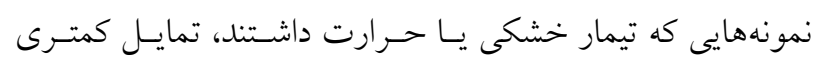

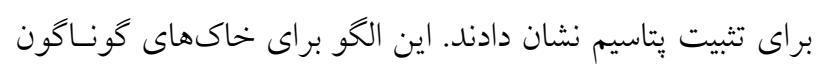

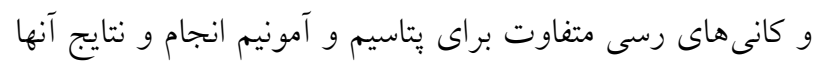

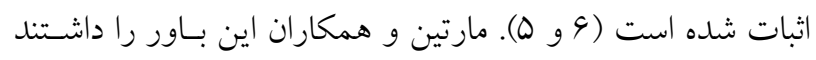

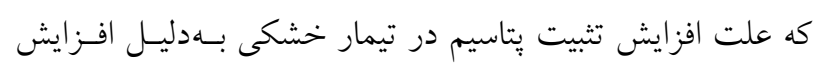

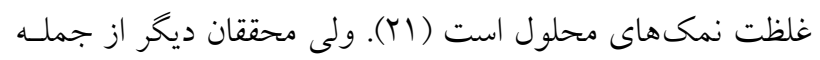

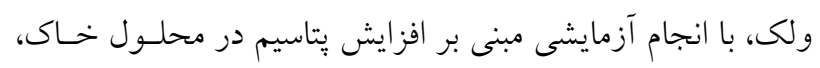

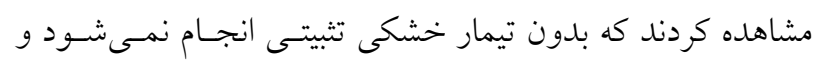

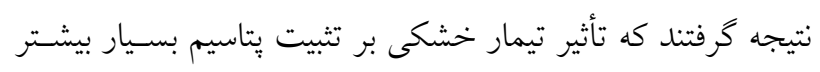

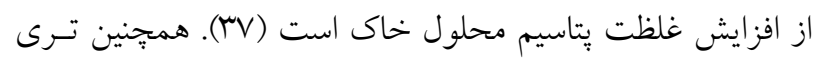

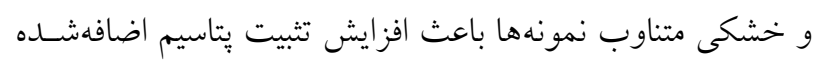

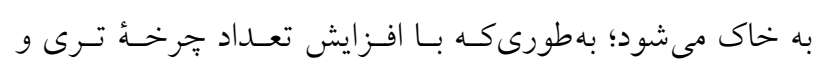

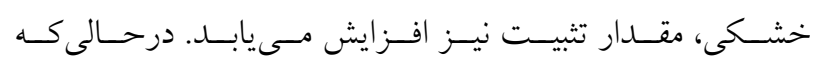

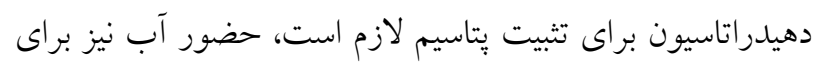

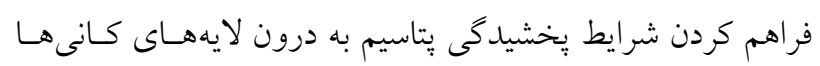

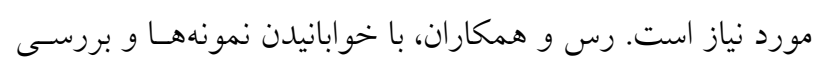

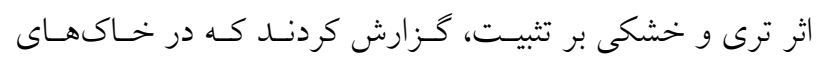

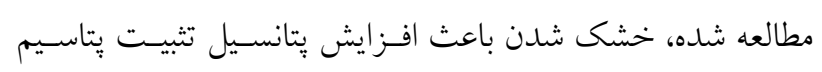

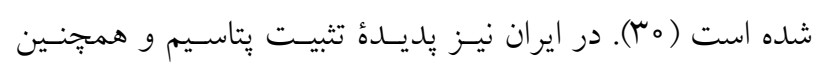

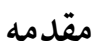

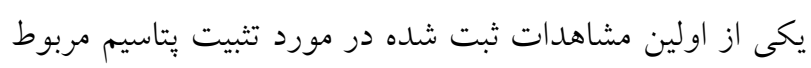

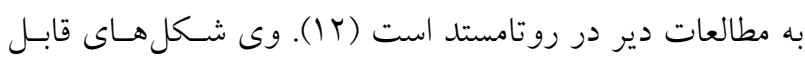

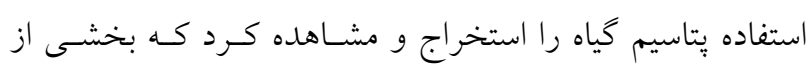

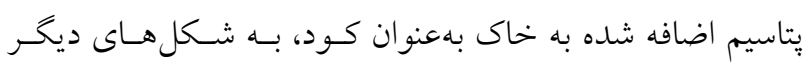

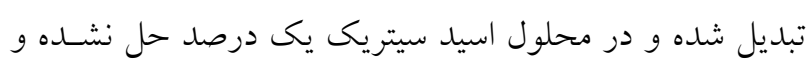

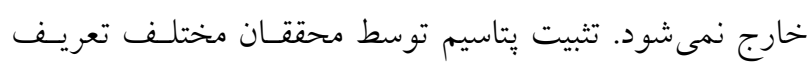
شده است. ترو و تامسون، بيان مىكنند كه تثبيت بِّاسـيم، تغييـر

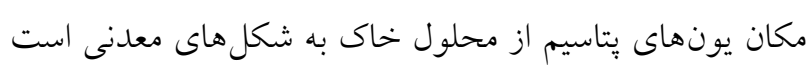

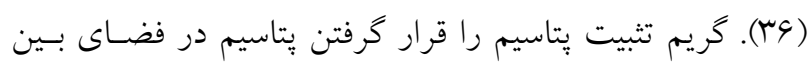

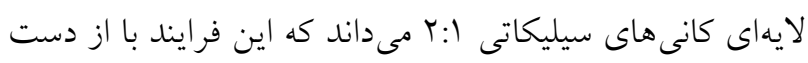

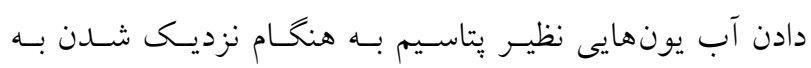

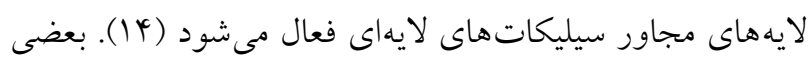

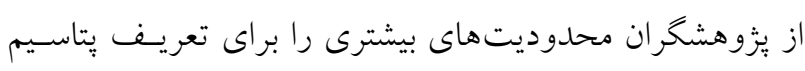

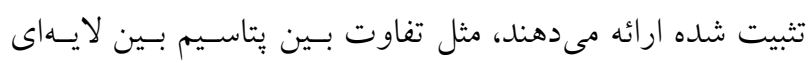

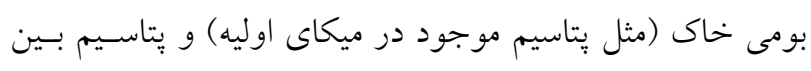

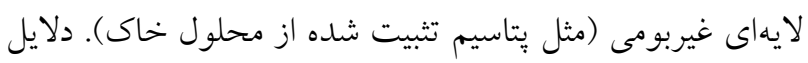

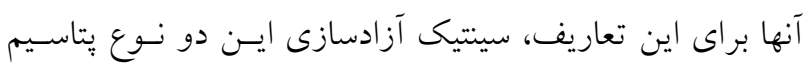

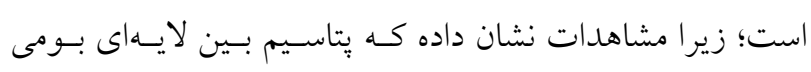

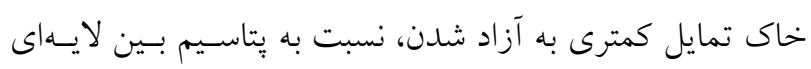
غيربومى خاكها، نشان مى دهد (Y).

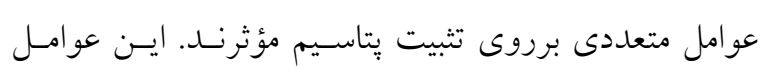

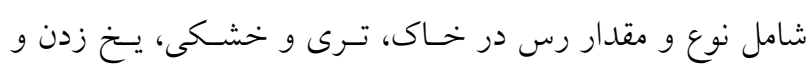

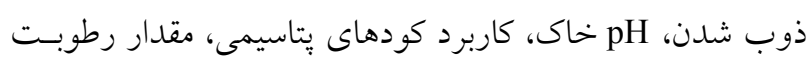
خاك و غلظت بِتاسيم در مقايسه با ساير كاتيونها مانند كلسيميم

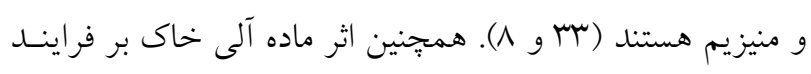
تثبيت يتاسيم در خاكها نيز اثبات شــده اسـت. مكانيســم تـأثير

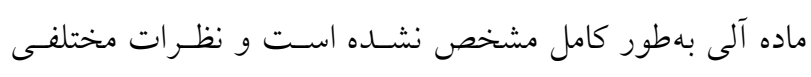

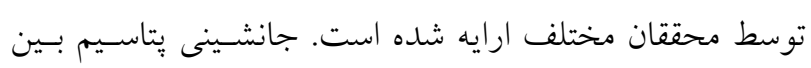

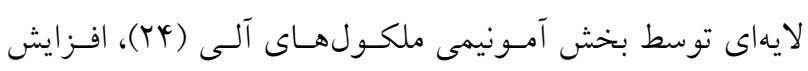

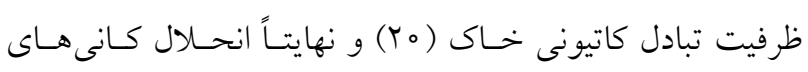

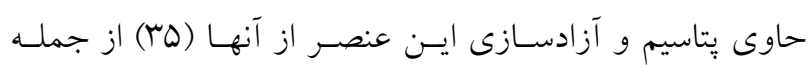


عكسهاى هوائى، نقشههاى تويوكرافى و بيمايش ميدانى، اقدام بـهـ

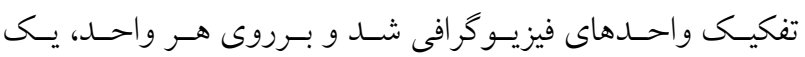

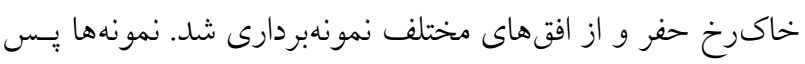

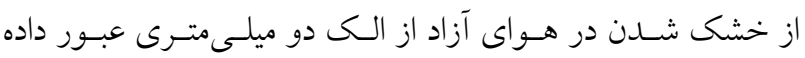

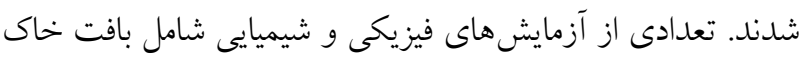
به روش هيدرومتر (V)، كربنات كلسيم معسادل بـه روش تيتراسـيون

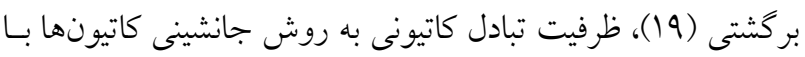

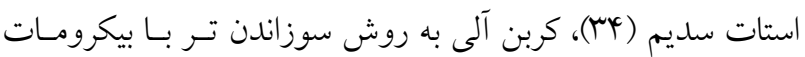

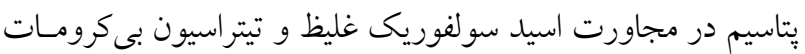

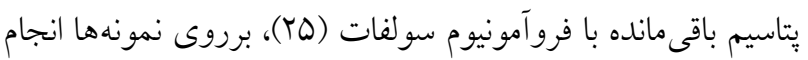
شد. همجنين، بتاسيم تبادلى از طريق عصارهذيرى با استات آمـونيم

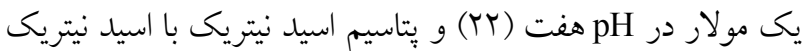
جوشان يك مولار (Tq) انجام شد. براى اندازهيرى مقدار تثبيت يتاسيم، بنج گرم از نمونه هاى

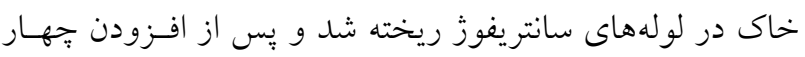

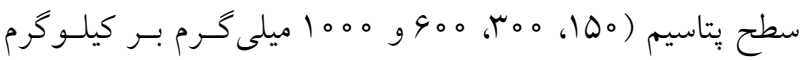

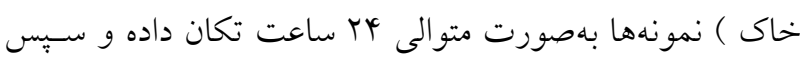

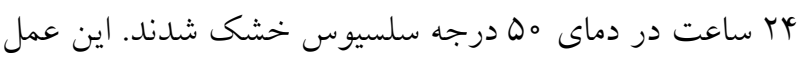

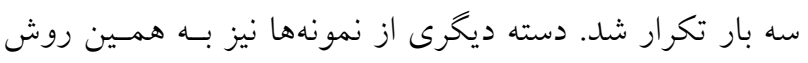

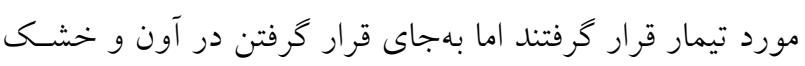

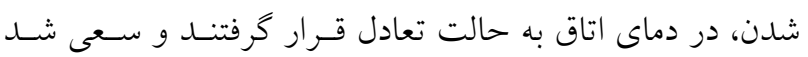

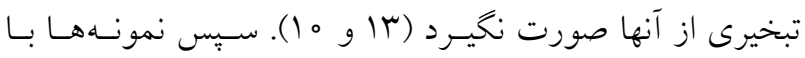

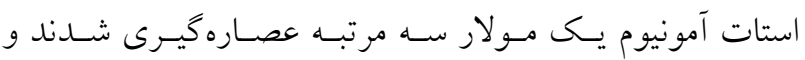
عصارههاى حاصل بس از به حجم رسيدن، بـراى انــازهذيـرى يتاسيم به روش شعلهسنجى نخهدارى شد. مقدار يتاسـيم تثبيـت شده نيز از رابطه زير محاسبه شد. هُاسيم تثبيت شده = (يتاسيم اضافه شده + يتاسيم بـومى خـاك)يتاسيم عصارهذيرى شده با استات آمونيم

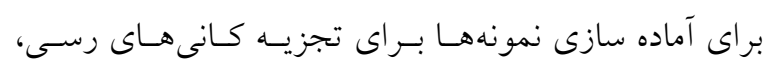

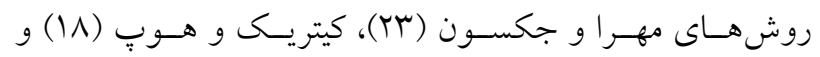
جكسون (19) براى از بين بردن عوامل شيميايى سيمانى كننده و جــدا

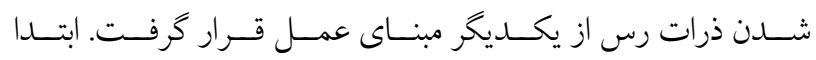

عوامـل مـؤثر بــر آن در بعضى از نقـاط كشـور توسط محققــان

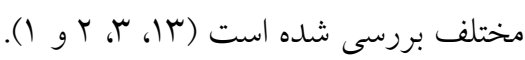

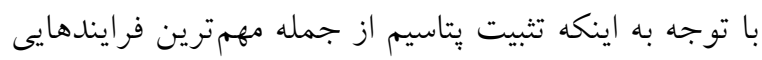

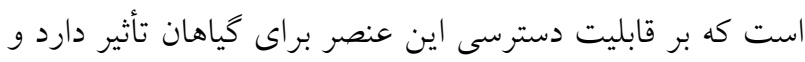

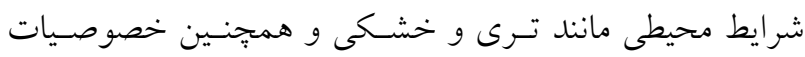

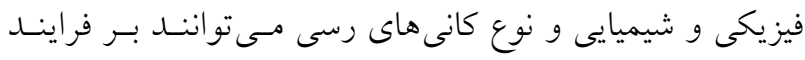

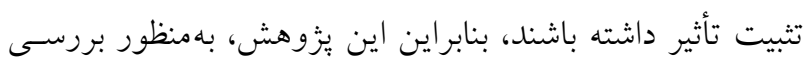

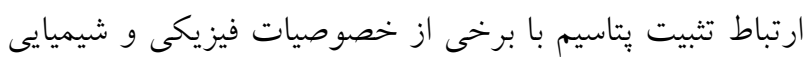

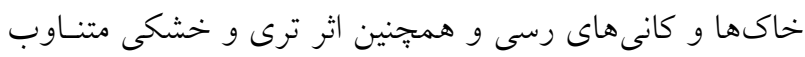

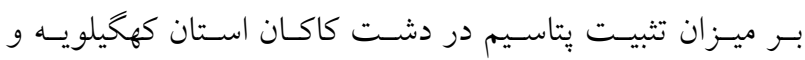

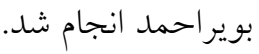

\section{مواد و روشها} موقعيت و ويزگى هاى منطقه

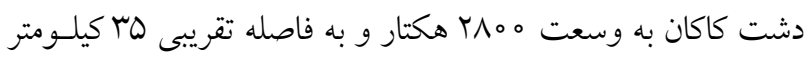

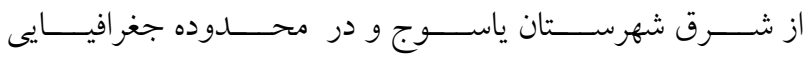

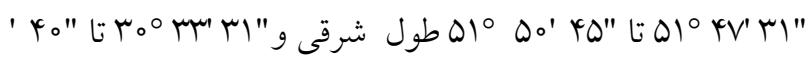

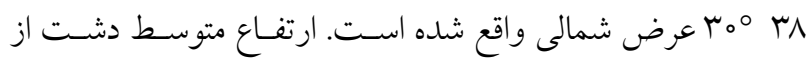

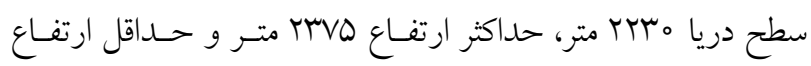

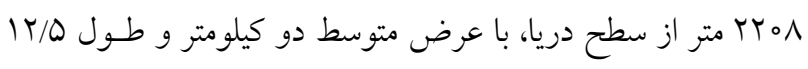

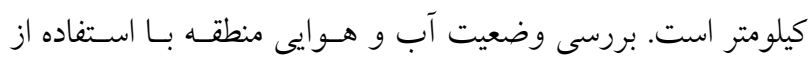

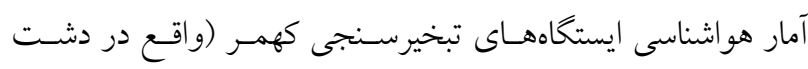

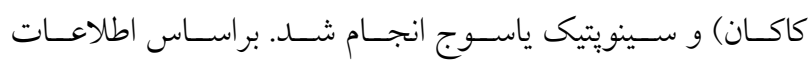

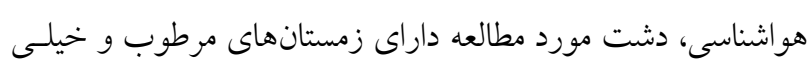

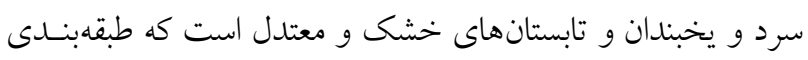

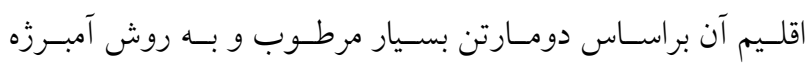

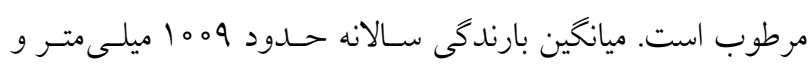

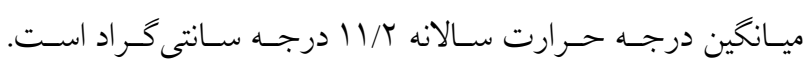
رزيمهاى رطوبتى و حرارتى منطقه بهترتيب زريكى و مزيكى است.

\section{روش انجام مطالعه}

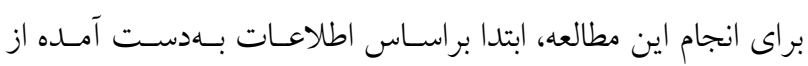


جدول ا. موقعيت و طبقهبندى خاكهاى منطقه براساس سيستم جامع طبقهبندى وزارت كشاورزى آمريكا (USDA) و فائو (WRB)

\begin{tabular}{|c|c|c|c|}
\hline USDA (2014) & WRB (2014) & فيزيوگر افى & شماره خاكرخ \\
\hline Fine, carbonatic, mesic, Typic Calcixerepts & Haplic Calcisols & دشت مرتفع & 1 \\
\hline Fine, smectitic(calcareous), mesic, Calcic Haploxeralfs & Fluvic Clayic Calcic Luvisols & دشت مرتفع & r \\
\hline Fine, carbonatic, mesic, Typic Haploxeralfs & Clayic Haplic Luvisols & 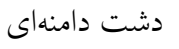 & r \\
\hline Fine, carbonatic, mesic, Aquic Haploxeralfs & Gleyic Haplic Luvisols & 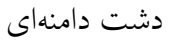 & r \\
\hline Fine, smectitic(calcareous), mesic, Typic Haploxerolls & $\begin{array}{c}\text { Cambic Loamic Haplic } \\
\text { Kastanozems }\end{array}$ & دشت دامنهاى & 0 \\
\hline Fine, smectitic(calcareous), mesic, Typic Argixerolls & LuvicChernozems & دشت دامنهاى & 9 \\
\hline
\end{tabular}

مقابل هواديدكى، خاكهاى متنوعى تشكيل شده است. بـا توجـه بـهـ

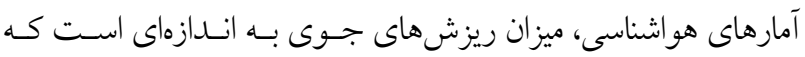

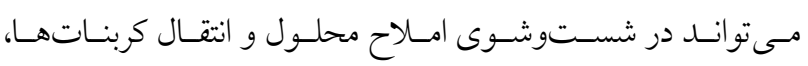

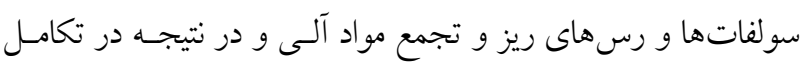

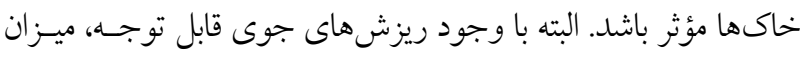

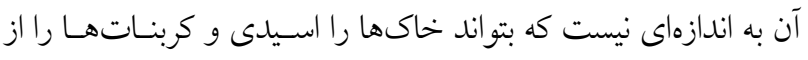

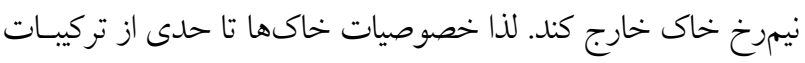
مواد مادرى تبعيت مى كند. به نظر مسىرســـ ميـزان زيـاد آهـى مـانع

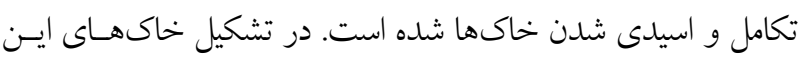
منطقه عامل اقليم بيش از ساير عوامل تشكيل دهنده خاك مـؤثر بـوده

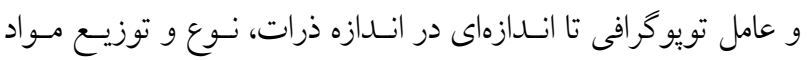

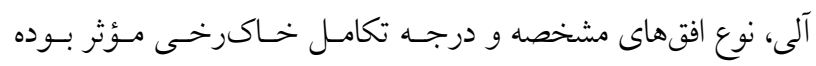
است. در حقيقت، نسبت به سـاير منـاطق مديترانساى جنسوب ايـران،

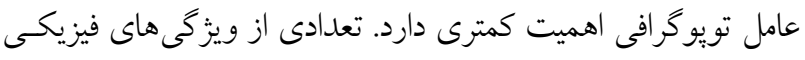
و شيميايى خاكهاى منطقه در جدول (Y) آورده شده است.

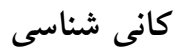

فراوانى نسبى كانىهاى رسى در خاكهاى منطقه كاكـان در جــدول

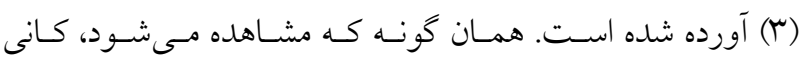

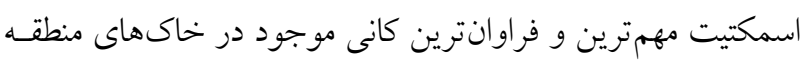

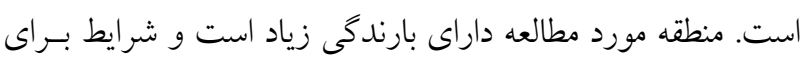

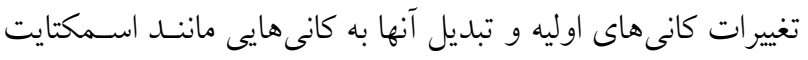

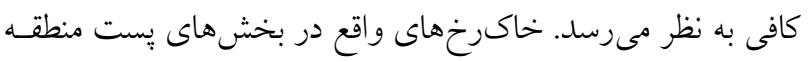
داراى بافت ريز و شر ايط زهكشى نامناسـب هستند. بنـابراين،

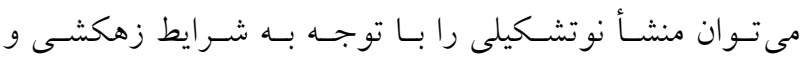

كربناتهاى خاك با استفاده از محلول نرمـال اسـتات ســيم (ه هH)

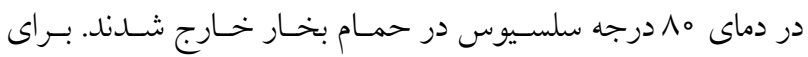

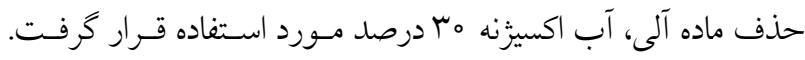

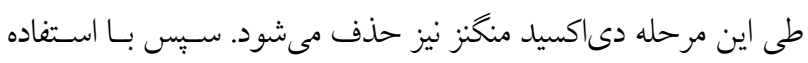

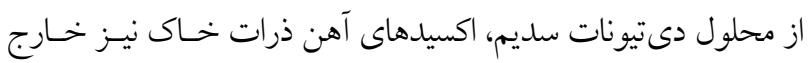

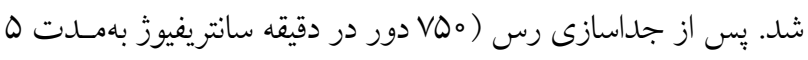

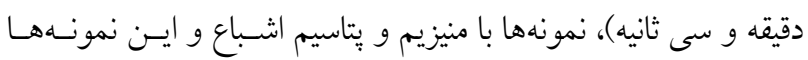

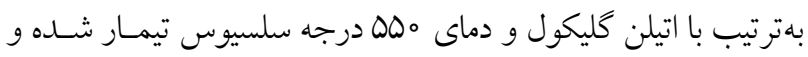
جداكانه با يراش برتو ايكس مورد بررسى قرار خرفتند.

\section{نتايج و بحث}

\section{ردهبندى خاكهاى منطقه}

بلطور كلى، خاكهاى منطقه با توجه به افق هاى مشخصه سططحى و

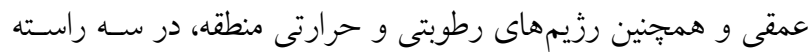

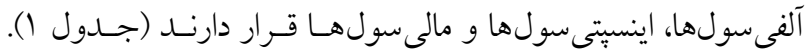
افقهاى مشخصه شامل افقهاى مشخصه سطحى اكريك و ماليكى و

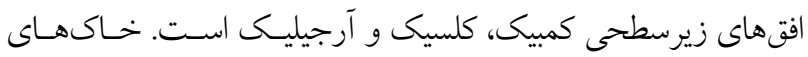

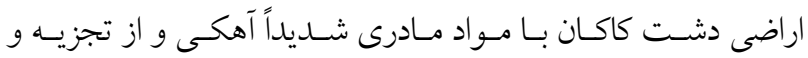

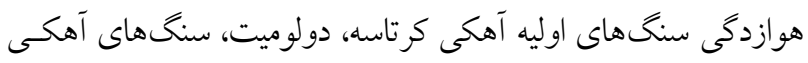

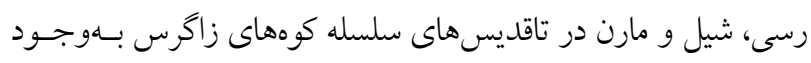

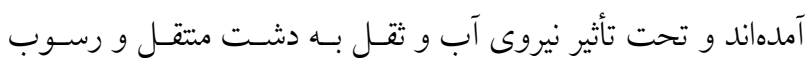

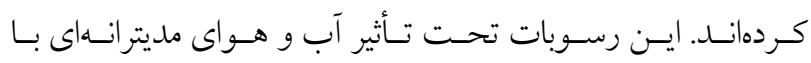

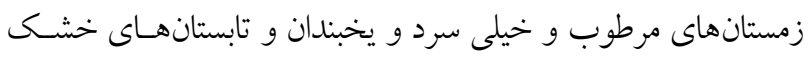

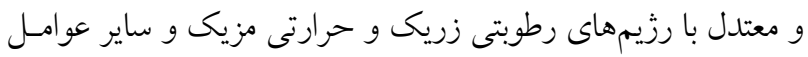

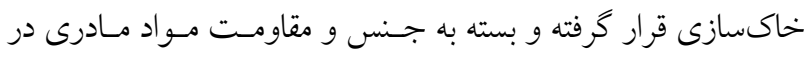


جدول r. تعدادى از ويزّكىهاى فيزيكى و شيميايى خاكهاى منطقه كاكان

\begin{tabular}{|c|c|c|c|c|c|c|c|c|c|}
\hline يتاسيم غير تبادلى & $\begin{array}{l}\text { بتاسيم تبادلى } \\
\text { (mg Kg }\end{array}$ & $\begin{array}{c}\text { CEC } \\
\left(\mathrm{cmolc} \mathrm{kg}^{-1}\right)\end{array}$ & كربن آلى & كربنات & شن & رس & \multirow{2}{*}{ شمونه } & \multirow[t]{2}{*}{ افق } & \multirow{2}{*}{ شاكرخ } \\
\hline & & & \multicolumn{4}{|c|}{$(\%)$} & & & \\
\hline MYl & TOI & $\mu_{0}$ & $1 / 91$ & $\psi \wedge$ & YY & ky & 1 & Ap & \multirow{2}{*}{1} \\
\hline 119 & 91 & rr & $1 / 0 \wedge$ & rV & rq & rV & r & $\mathrm{Bk}_{1}$ & \\
\hline DYT & yor & rq & $1 / \pi 9$ & TY & IV & س & 0 & Ap & \multirow{2}{*}{ r } \\
\hline$|4|$ & r & r & $\circ / V Q$ & $\varphi_{0}$ & YI & 40 & v & $\mathrm{Btk}_{1}$ & \\
\hline rMV & $|\wedge|$ & d & $1 / 0 r$ & Or & V & $\Delta \Delta$ & r & Ap & \multirow{2}{*}{$\varphi$} \\
\hline 111 & 119 & $\mu r$ & $0 / 9$ & $\Delta V$ & r & 91 & 14 & $\mathrm{Btkg}_{1}$ & \\
\hline$r 90$ & $19 \mathrm{~V}$ & ry & $\circ / \Lambda$ & 40 & 11 & id & 11 & $\mathrm{Bw}_{1}$ & \multirow{2}{*}{0} \\
\hline TOI & 109 & $y_{0}$ & o/Qr & id & $\wedge$ & 49 & ro & $\mathrm{Bw}_{3}$ & \\
\hline
\end{tabular}

جدول r. فراوانى نسبى (درصد) كانىهاى رسى در خاكهاى منطقه كاكان

\begin{tabular}{|c|c|c|c|c|c|c|c|}
\hline كوارتز & ورمى كولايت & اسمكتيت & كلريت & ايليت & كائولينيت & افق & خاكرخ \\
\hline+ & + & +++ & ++ & + & + & Ap & 1 \\
\hline+ & + & ++++ & ++ & + & + & Bk1 & 1 \\
\hline+ & + & +++ & ++ & + & + & Ap & r \\
\hline+ & + & ++++ & ++ & + & + & $\mathrm{Bw}$ & r \\
\hline+ & + & +++ & ++ & + & + & Ap & r \\
\hline+ & + & ++++ & ++ & + & - & Btkg1 & r \\
\hline
\end{tabular}

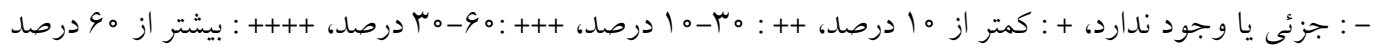

از سطح بـه عمق بهدليل آبورهواى مرطوب منطقه عنـوان نمـود. در سطح خاك شرايط براى تبديل كانىهاى ديخر مانند ايليت و باليخورسكيت به اسمكتايت مهياتر است، ولى بارندگى منطقه و

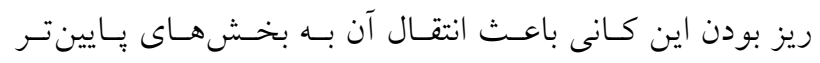

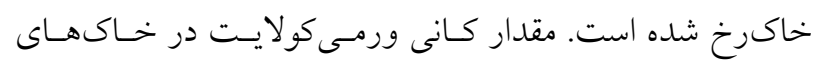
منطقه كمتر از ها درصد است و اختلاف معنى دارى در ميزان اين كانى بين افتهاى سطحى و عمقى وجود ندارد. دليل كم بـودن ميزان ورميكولايت در خاكهاى منطقه را مىتوان نايايـدارى آن در شرايط منيزيم زياد و pH قليـايى خـاك دانسـت كـه باعـث نايايدارى اين كانى در شرايط تشكيل از ميكا شده است و باعث مىشود كه اين كانى به سرعت به اسمكتايت تبديل شـود (IV).

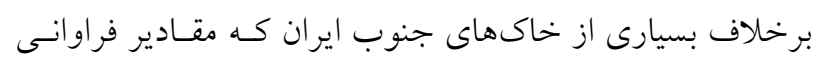
كانى ايليت دارند، ميزان اين كانى در منطقه بسيار كم اسـت كـه

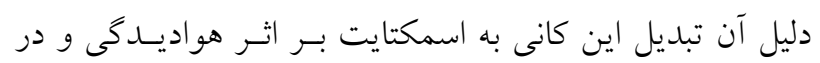

همجنين pH بالا و فعاليت بالاى يون سـيليس در ايسن شـرايط، يكى از مهمترين دلايل فراوانى اسمكتايت در ايسن خـاكرخهـا دانست. منشأ ديخرى كه براى درصد بالاى اين كانى در اراضسى يست منطقه مىتوان عنوان كرد، تبديل كانى ياليخورسـكايت بـهـ

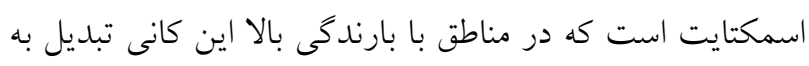
اسمكتايت مىشود. در اين منطقه نيز در هيج كدام از خاكرخها كانى پاليخورسكيت مشاهده نشد. اوليايى و همكاران در بررسى

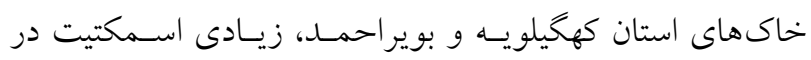
خاكهاى مناطق با بارندگى كـم تـا متوسـط را مـواد مـادرى و سنگ مادر و در مناطق با بارندگى بيشتر، نوتشكيلى و تجزيسه و تخريب ساير كانىها و همجنين تبديل بِاليخورسكيت به مونست

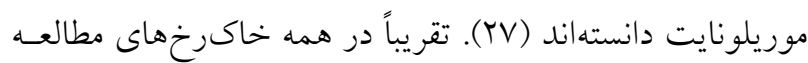
شده، ميزان اسمكتايت از سطح بـه عمـق افـزايش يافتـه اسـت.

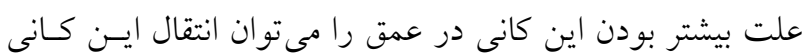


جدول أ. مقادير و درصد يتاسيم تثبيت شده در دو حالت عادى و ترى و خشكى در منطقه كاكان (mg Kg-1)

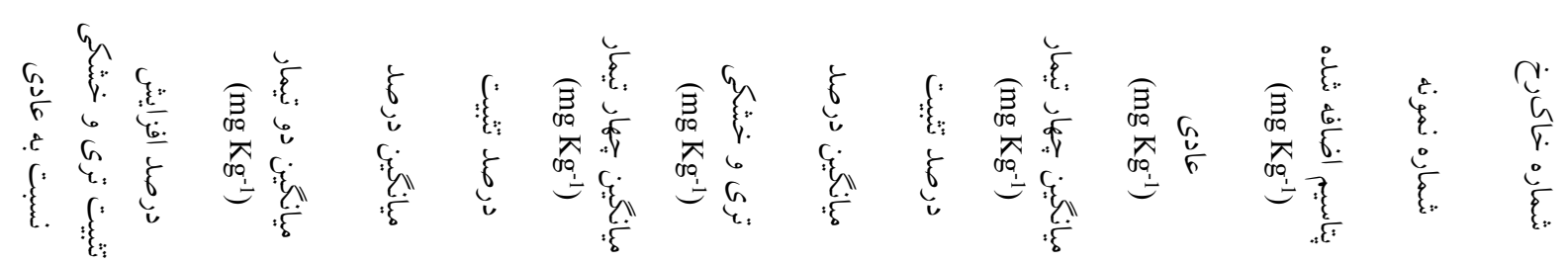

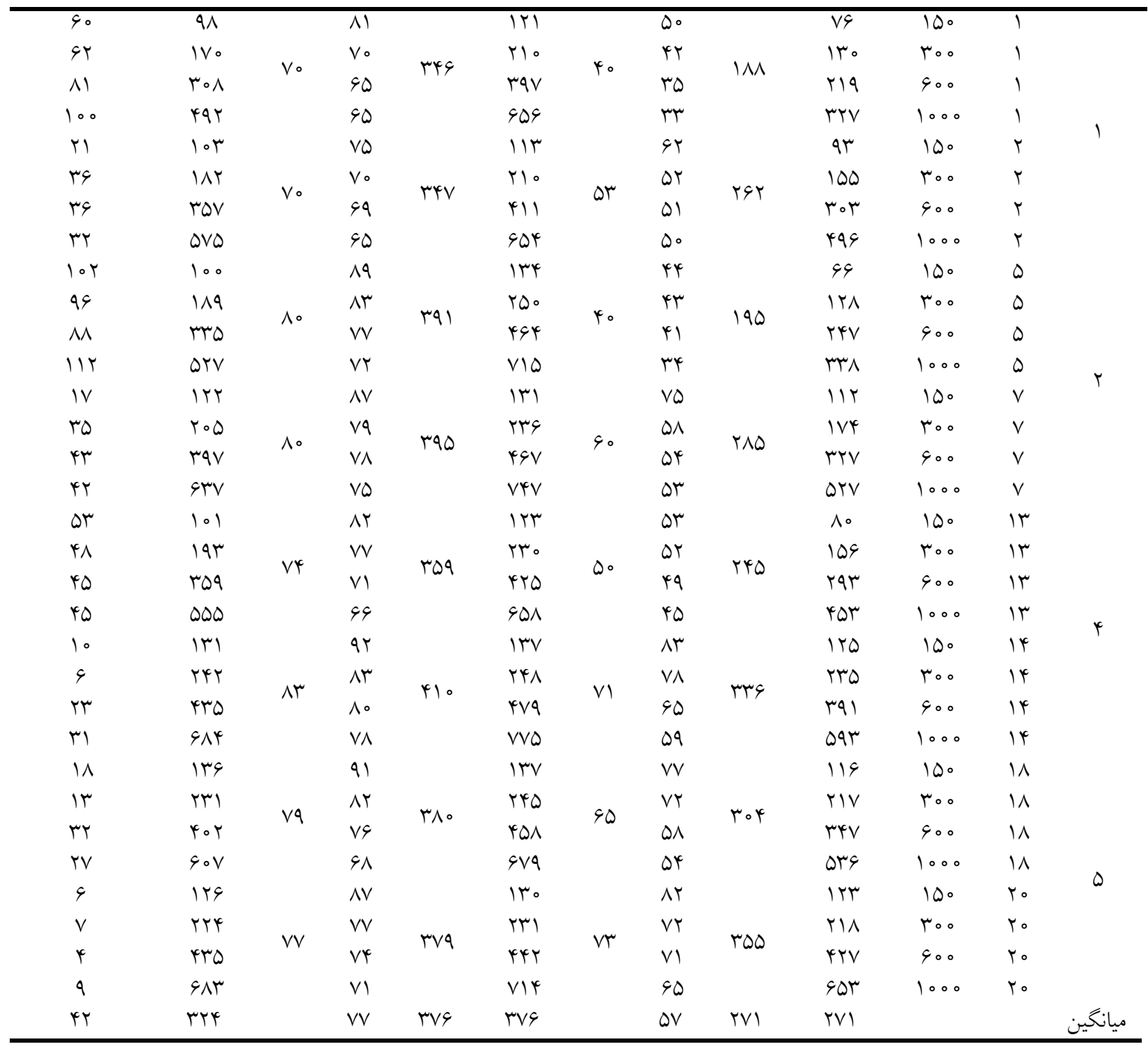

نتيجه خارج شدن يتاسيم و تبديل شدن آن به كـانى اسـمكتايت تثنبيت يتاسيم

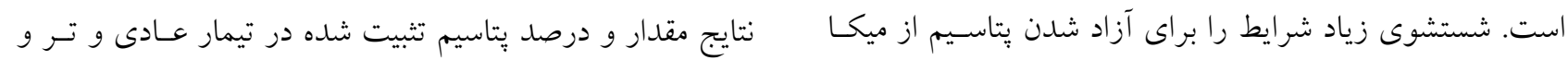

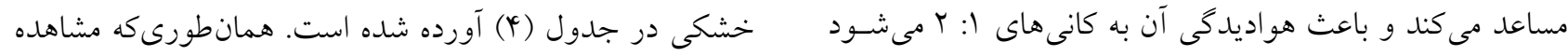

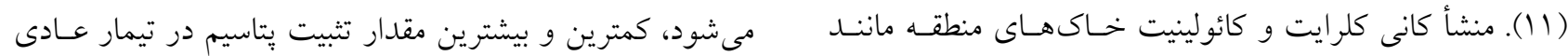

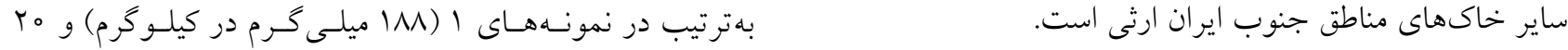




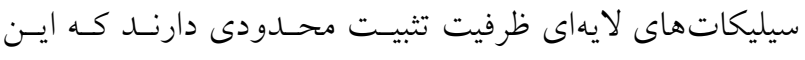

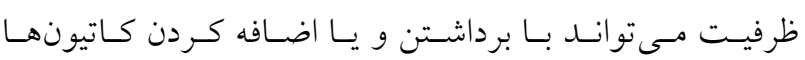

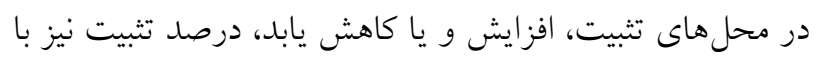

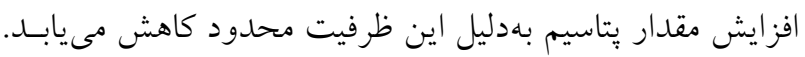

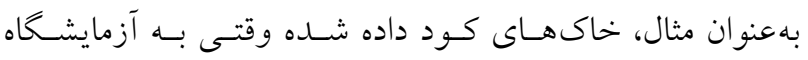

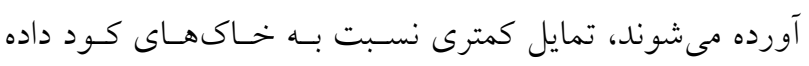

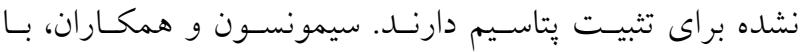
بررسى نقش افزودن يتاسيم از طريق كوددهى بر تثبيـت يُّاسـيم

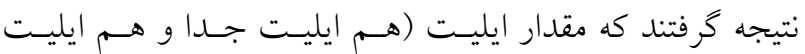

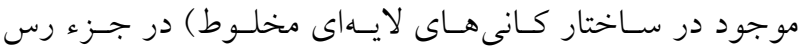
خاكها، در خاكهايى كه كود يتاسـيم بيشـترى دريافـت كـرده

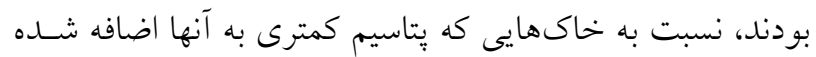

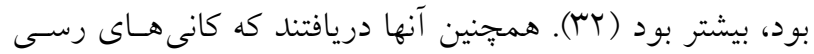
در خاكهاى حاوى كلسيت و يا خاكهاى محتسوى كانىهـاى اوليه قابل تجزيه و تخريب در بخش رس از شـرايط مـتلاطم و

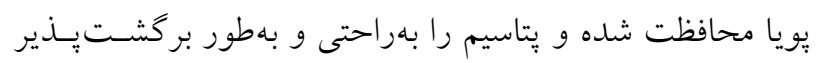

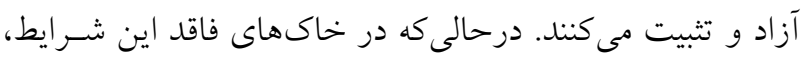

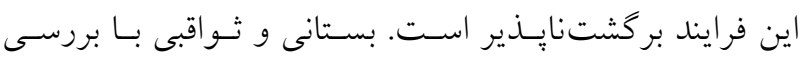

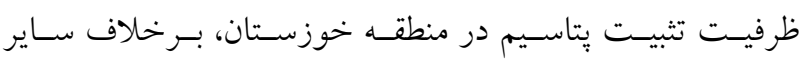

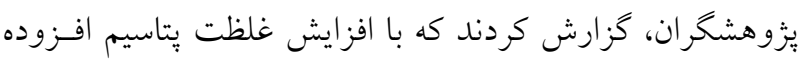

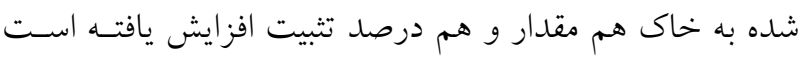

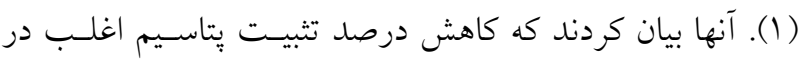

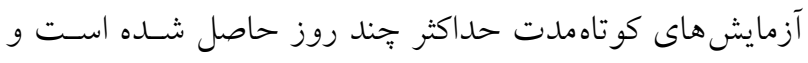

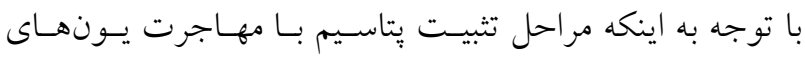

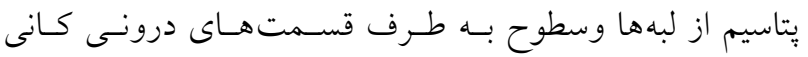
كسترش مى يابد و بهعلت كندى اين مراحـل، مقــار يـونى كـهـ

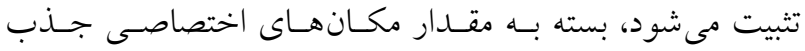

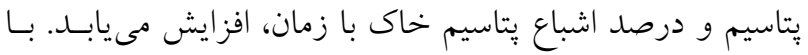

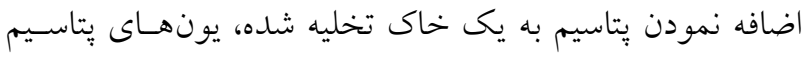

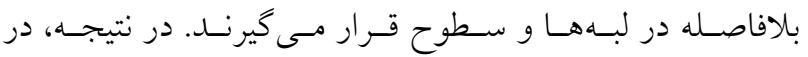

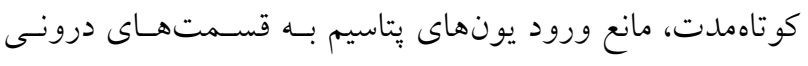

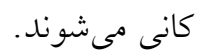

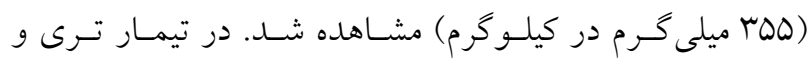

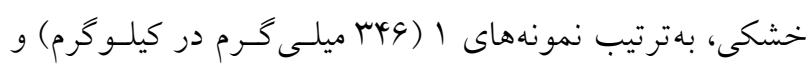

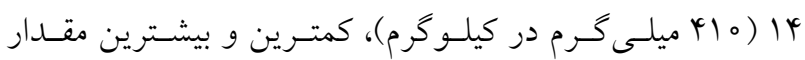

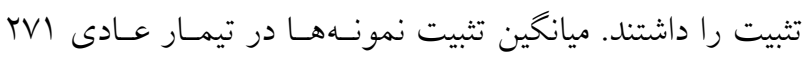

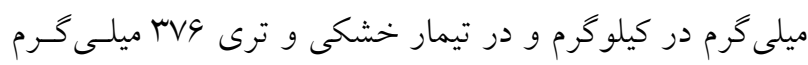

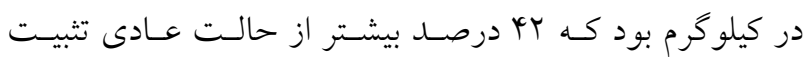
بتاسيم انجام شده است. خاكهــاى منطقـه داراى ايليـت بسـيار كمسى اسـت و اسـمكتايت كـانى غالـب منطقـه اسـت. وجـود اسمكتايتهاى با بار لايهاى بالا باعث شده است كه خـاكهـاى

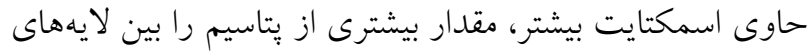

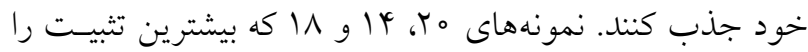

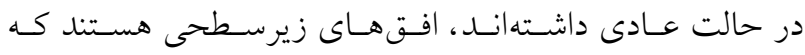
اسمكتايت بيشترى نسبت به افقهاى سطحى دارند.

\section{تأثير سطوح مختلف يُاسيم بر مقدار تثبيت}

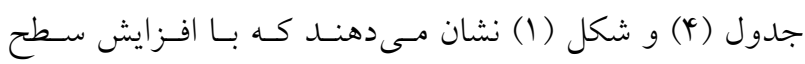
يتاسيم افزوده شده به خاك، مقدار تثبيت افزـايش ولى درصـد

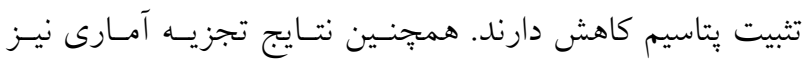
نشان داد كه بين سطوح بِتاسيم افزوده شده بـا تثبيـت بِّاسـيم و همجنين تيمار عادى و ترى و خشكى با مقدار تثبيت، اخستلاف معنى دارى وجود دارد (شكل Y). اين نتايج نشان مى دهد كـه در همه نمونهها كاربرد متفاوت سطوح بتاسيم باعث افزايش تثبيت شده است. در واقع با افزايش مقـدار بتاسـيم در خـاك، تعـادل

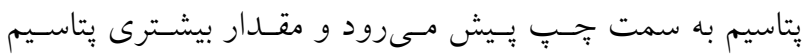
تثبيت مىشود كه ايـن در نتيجـهُ يتاسـيم اضـافى اسـت كـه بـهـ مكانهاى بين لايهاى تحميل مىشود و همجِنين يتاسـيم افزوده

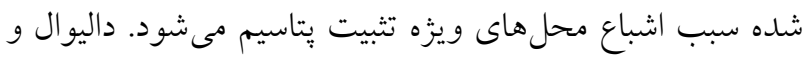

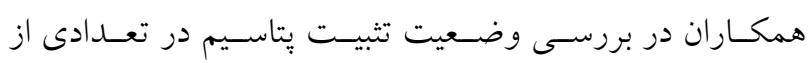
خاكهاى منطقهاى در شمال غربى هند، سطوح مختلف يتاسـيم

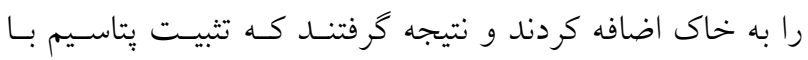

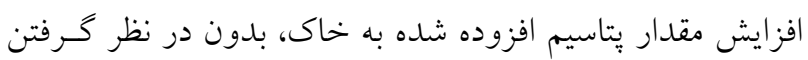

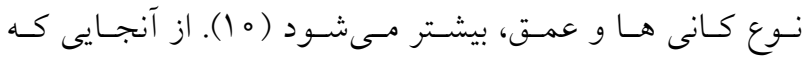




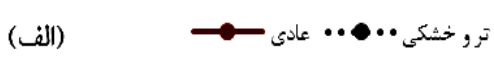

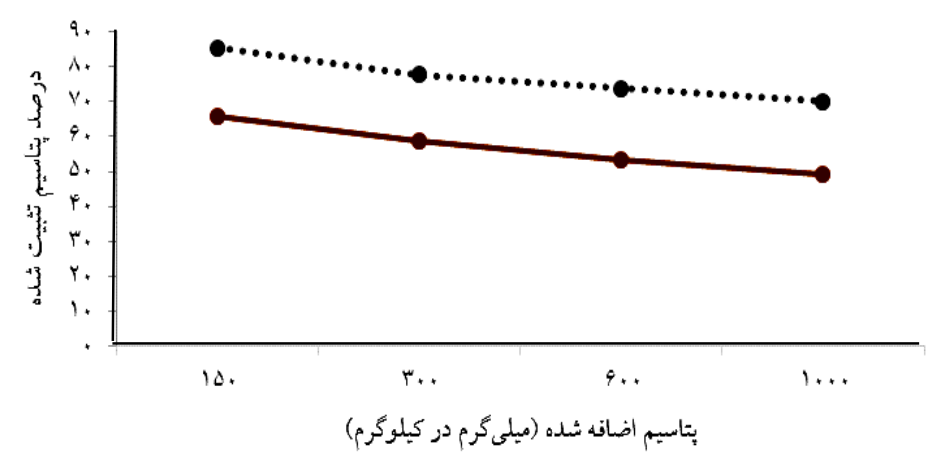

(ب)

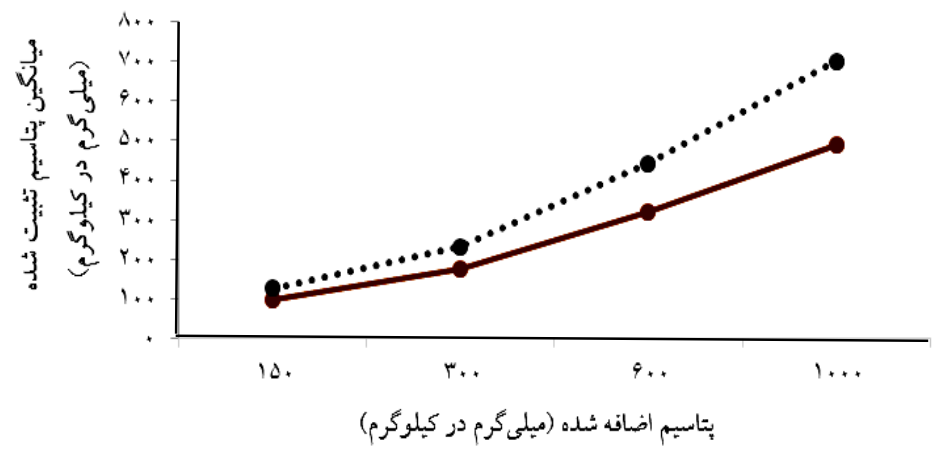

شكل (. الف) درصد و ب) ميانگين يتاسيم تثبيت شده در مقادير مختلف يتاسيم افزوده شده

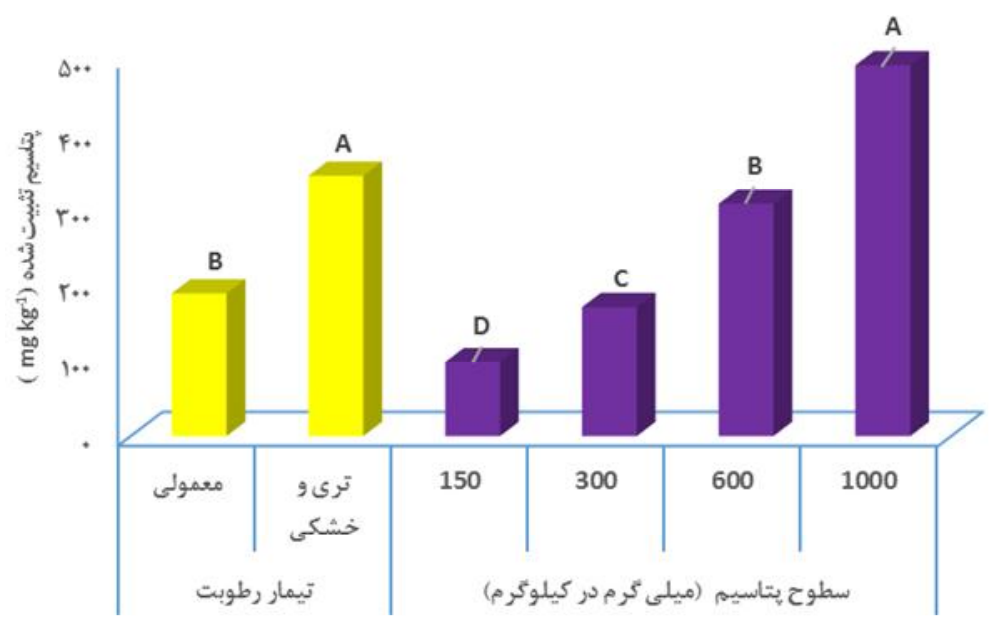

شكل Y. مقدار يّاسيم تثبيت شده در تيمارهاى معمولى و ترى و خشكى و با كاربرد مقادير مختلف يتاسيم (حروف غير يكسان نشاندهنده تفاوت معنىدار در سطح يك درصد از آزمون دانكن مى باشند) 
جدول ه. همبستخى بين تعدادى از ويزگگىهاى فيزيكوشيميايى با تثبيت يتاسيم در حالت عادى و تر و خشكى منطقه كاكان

\begin{tabular}{|c|c|c|c|c|c|c|}
\hline تثبيت عادى & ظرفيت تبادل كاتيونى CEC & كربن آلى & كربنات كلسيم & رس & شن & \\
\hline & & & & & $-0 / \Lambda ९ \Lambda^{* *}$ & رس \\
\hline & & & & $0 / 0 r_{q}$ & $-0 / 0 \vee 9$ & كربنات كلسيم \\
\hline & & & $\circ / 0{ }^{\prime}$ & $-0 / r \Delta q$ & $0 / 491$ & كربن آلى \\
\hline & & $-0 / 490$ & $-0 / 494$ & $0 / 9 \mathrm{Vr}$ & $-\circ / \vee 9 r^{*}$ & ظرفيت تبادل كاتيونى \\
\hline & $\circ / Y V \Lambda$ & $-\circ / \Lambda \Lambda \mu^{* *}$ & $\circ / \circ V_{1}$ & ०/T^צ & - ०/OHI & تثبيت عادى \\
\hline $0 / 490$ & $0 / 919$ & $-\circ / V Q_{0}^{*}$ & $-0 /$ KYY & $0 / 990$ & $-0 / 091$ & تثبيت ترى و خشكى \\
\hline
\end{tabular}

ظرفيت تبادل كاتيونى خاك ارتباط مثبـت و معنسىدارى وجـود دارد (4). اين در حالى است كه جيتامـارت و همكـاران، اعـلام كردند كه بين ظرفيت تثبيت يتاسـيم و ظرفيـت تبـادل كـاتيونى ارتباط بسيار ضعيفى وجود دارد (9). با توجه به اينكه ظرفيـت

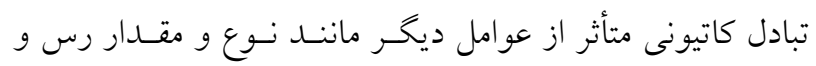
همجنين ميزان ماده آلى است، اثر اين عامل بايد با بررسسى ايسن

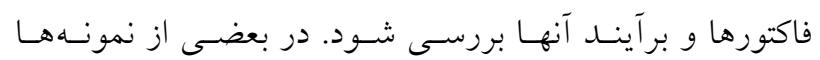
(نمونههاى ا و ه) باوجود ظرفيت تبادل كاتيونى زياد، بـهدليـل وجود ماده آلى بيشتر، مقدار تثبيت كم است؛ در صورتى كـه در

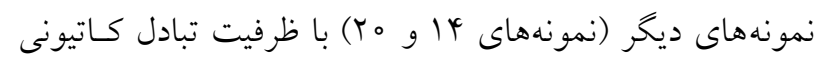
بيشتر، بهدليل اينكه ظرفيت تبادل كاتيونى ناشى از مقدار و نـوع رس است، ميزان تثبيت زياد است. اغلـب مكـان و جايخـاه بـار لايهاى يك فاكتور بسيار مهم در قدرت آن براى كنترل تثبيـت و آزادسازى در نظر كرفته مى شود. بار منفى با منشأ صفحه تجهـار

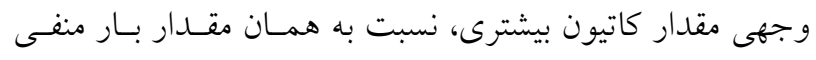
معادل كه منشأ آن صفحه هشت وجهى است، تثبيت مى كند كـه دليل آن نزديكى بارها به سطح بين لايهاى كانى هـا اسـت ( آم). اين موضوع توسط بوعبيد و همكارن نيز تأييد شـده اسـت (9).

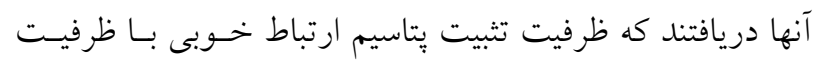
تبادل كاتيونى لايه جهاروجهى دارد، درحالى كه ارتباط ضعيفى با ظرفيت تبادل كاتيونى لايه هشت وجهى نشان داد. حسينيـور و

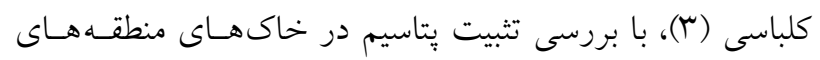

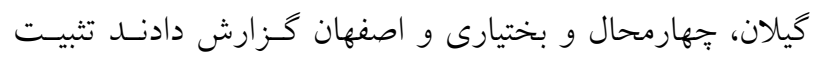

ارتباط تثبيت يتاسـيم بـا خصوصـيات فيزيكسى و شـيميايى خاكها، كانىهاى رسى و ترى و خشكى جدول (ه) همبستخى بـين تعـدادى از ويزّكى هـاى فيزيكى و شيميايى در حالت عادى و تـرى و خشـكى بـر تثبيـت يتاسـيم افقهاى سطحى و زيرسطحى را نشان مى دهد. همـان كونـهـ كـه مشاهده مىشود، تثبيت يتاسيم در حالت عادى و ترى و خشكى با ظرفيت تبادل كـاتيونى و مقـدار رس همبسـتخى مثبـت دارد.

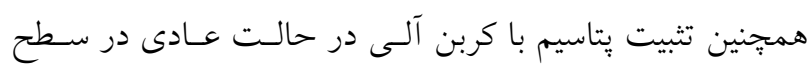
يك درصد و در حالت تـرى و خشـكى در سـطح يـنج درصــ همبستخى منفى نشان داد. ظرفيت تبادل كاتيونى خاى از عوامل مؤثر بر مقـدار تثبيـت يتاسيم است. بهدليل ارتباط تثبيت يتاسيم با بار لايهاى، مى تـوان استباط كرد كه تثبيت يتاسيم با ظرفيت تبادل كاتيونى نيز مرتبط است. در واقع، مقدار ظرفيت تبادل كاتيونى، نشاندهندهُ قـدرت جذب كاتيونهاى مختلف از جمله يتاسـيم توسـط كلوييـدهاى خاى است و با افزايش آن، قدرت جذب كـاتيونهـا بـهوسـيله كلوييدها افزايش مىيابد. همانكونه كه مشاهده مسىشـود، بـين

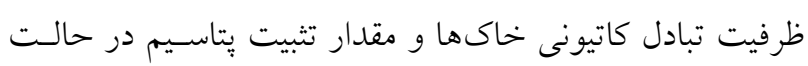
عادى ارتباط مثبت و ضعيف و در حالت ترى و خشكى ارتباط مثبت و قوىترى وجود دارد. اين ارتباط بيانكر اين است كه بـا افزايش ظرفيت تبادل كاتيونى خاك، مقـدار تثبـت بـتاسـيم نيـز

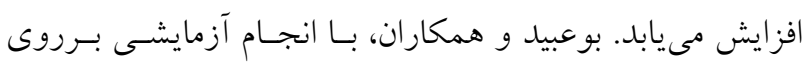
تعدادى از رسها مشاهده كردند كه بين مقدار تثبيـت يتاسـيم و 

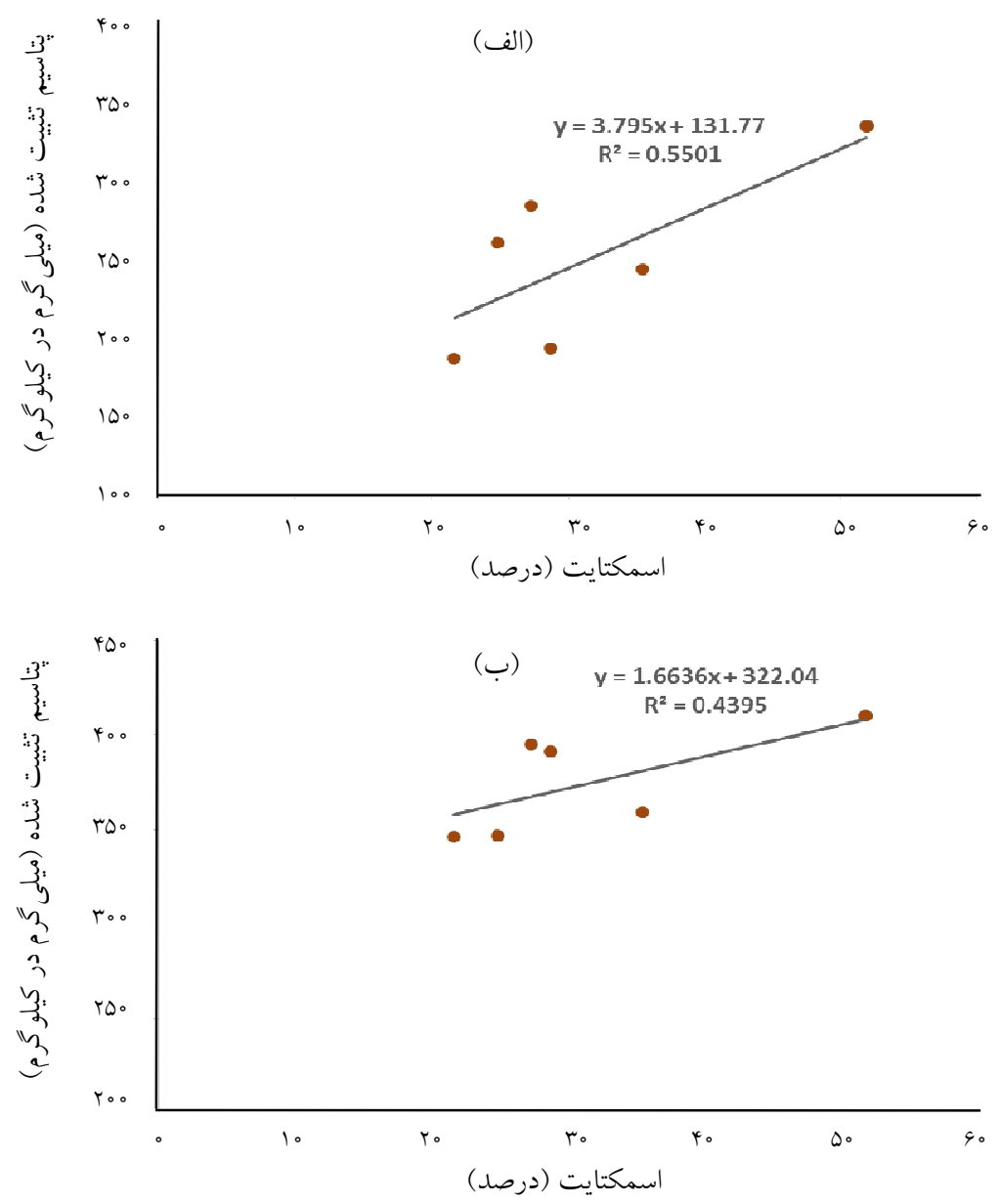

شكل r. ارتباط بين تثبيت يتاسيم و مقدار اسمكتايت خاك حالت الف) عادى و ب) ترى و خشكى (درمك

مطالعه شده داراى كانى اسمكتايت به مقدار زياد بودنـــ. شـكل

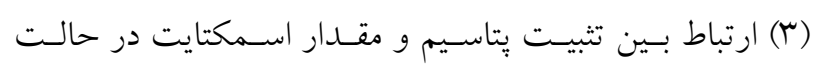

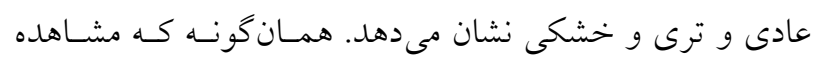

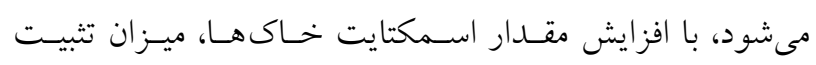

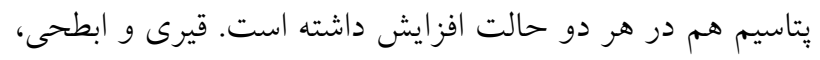

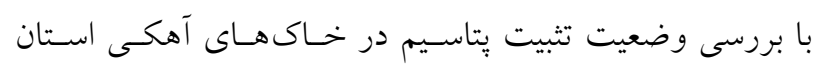

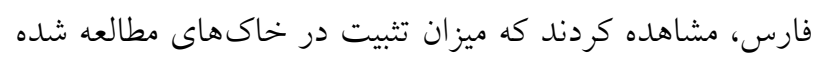

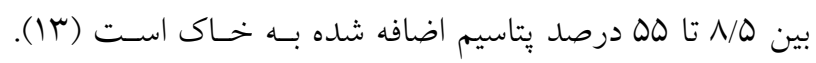

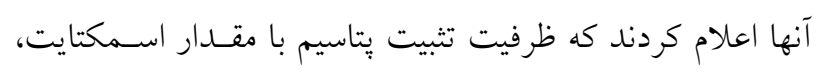

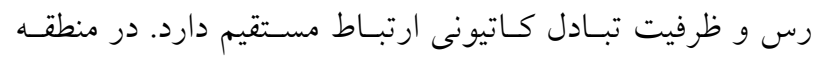

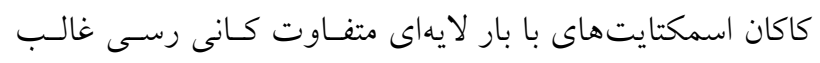

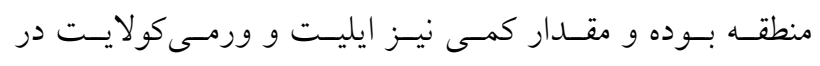

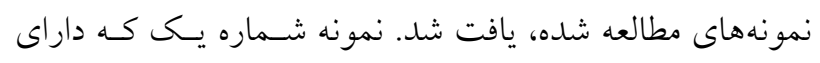

يتاسيم در رسهاى منطقه اصفهان بـا كنجـايش تبـادل كـاتيونى

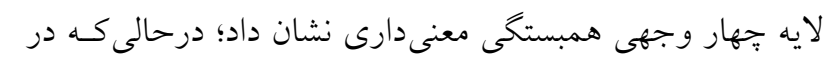

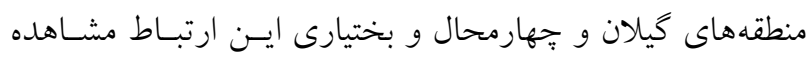

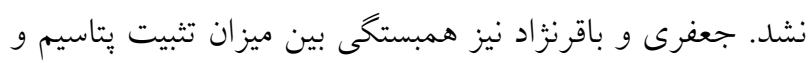

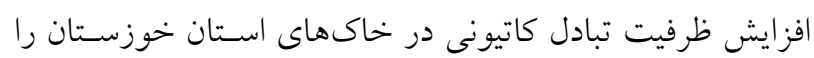
كزارش كردند (Y) (Y).

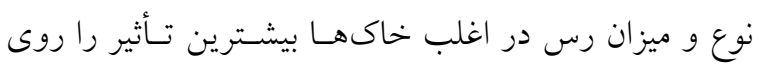

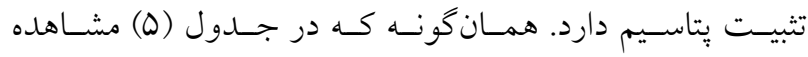

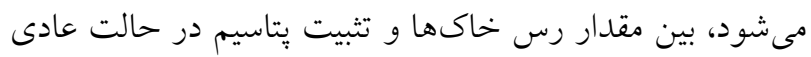

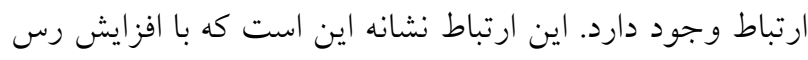

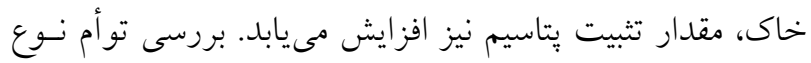

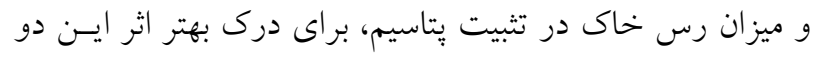

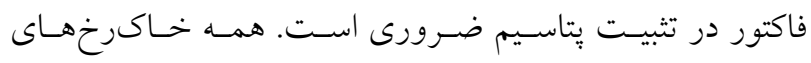


لايهاى و انبساط لايهها، افزايش ظرفيت تبادل كـاتيونى خـاك و

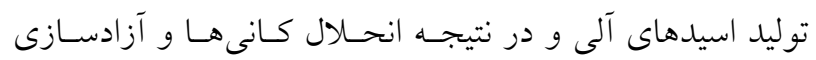

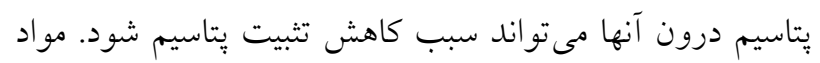

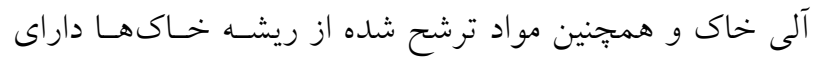

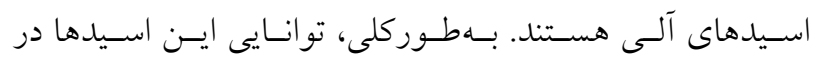

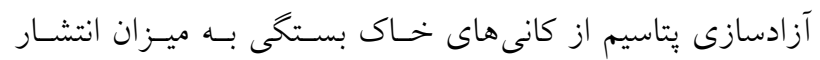

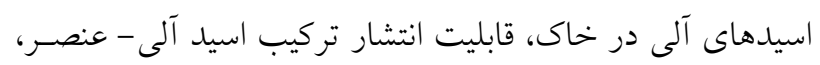

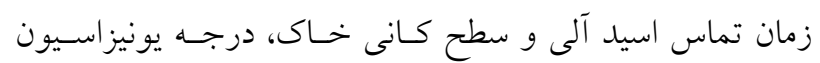

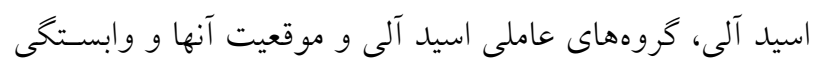

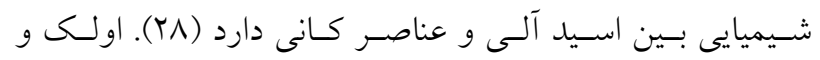

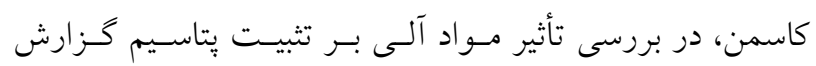

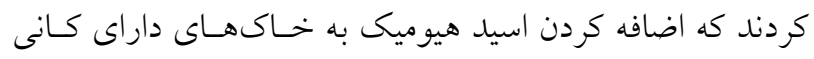

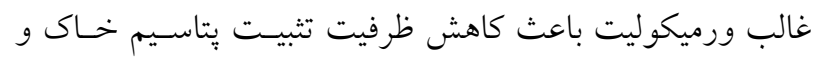
در نتيجه افزايش يتاسيم قابل استفاده شده است (Y) (Y). آنها اعلام

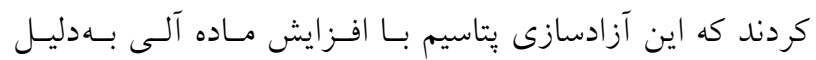

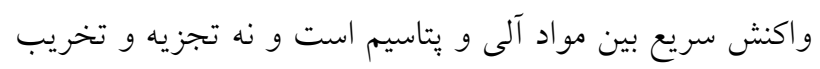

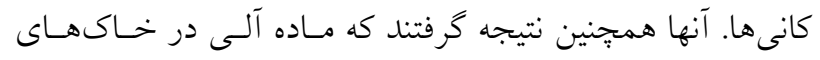

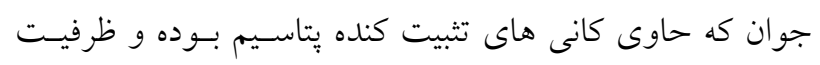

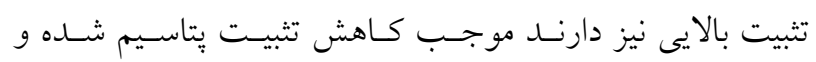

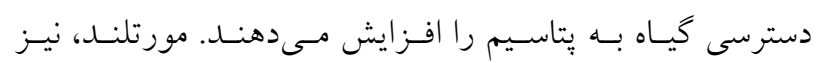

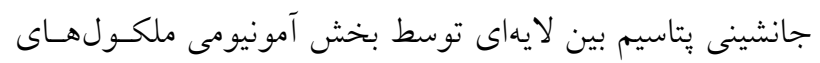

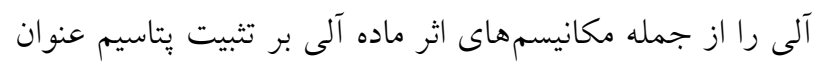

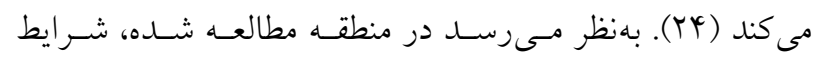

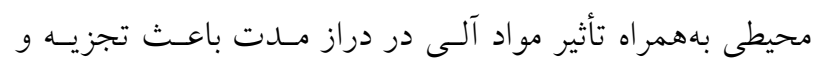

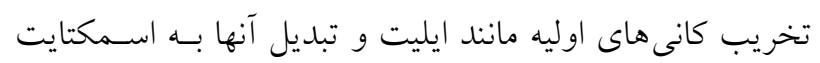

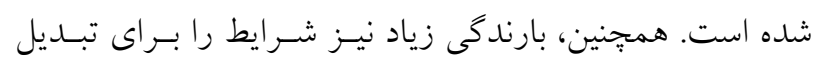

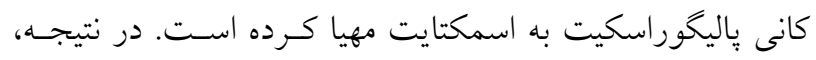

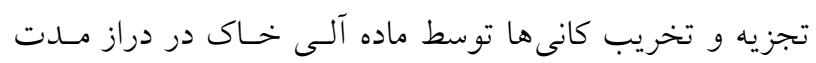

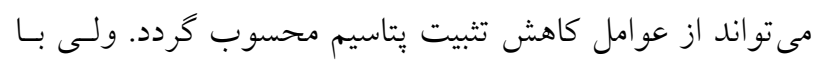

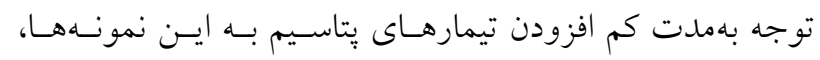

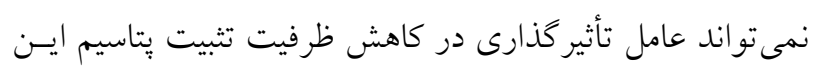

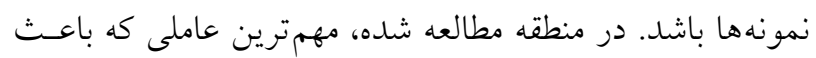

كمترين ميزان اسمكتايت و همجنين رس كمترى است كمتـرين

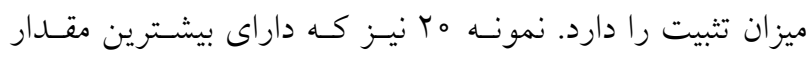

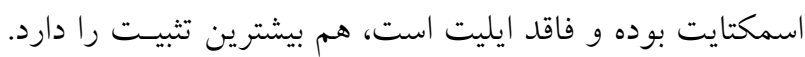

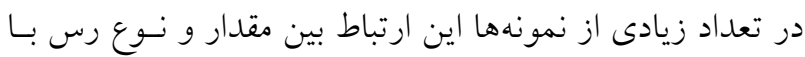

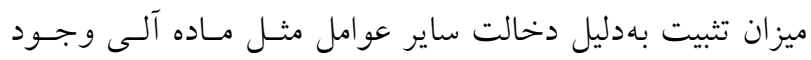
نداشت. از سه كانى مسؤول تثبيـت بتاسـيم در خـاك، معمـولاً

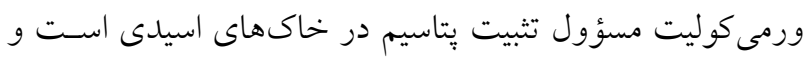

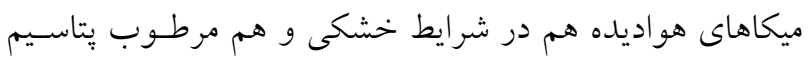

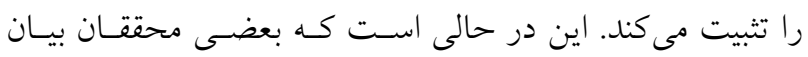

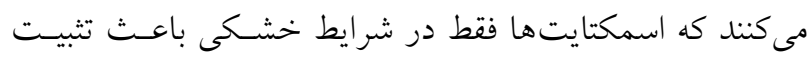
يتاسيم مى شوند و در حالت مرطوب نمىتو انند يتاسيم را تثبيت

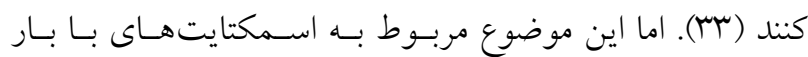

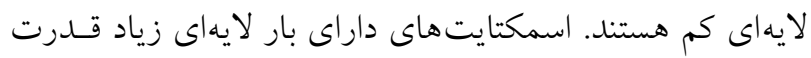

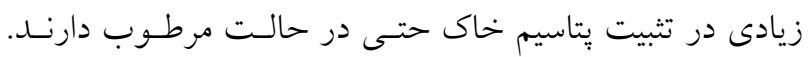

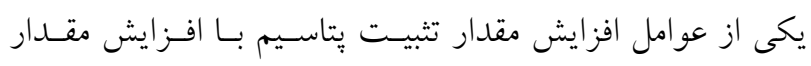

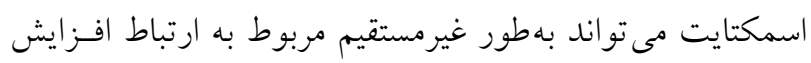

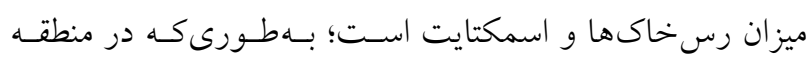

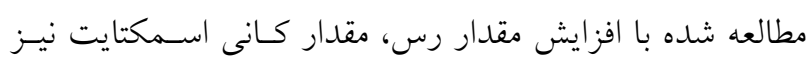

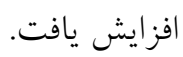

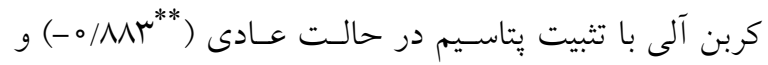
در حالت ترى و خشكى(

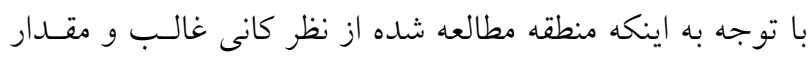

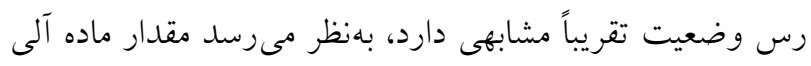

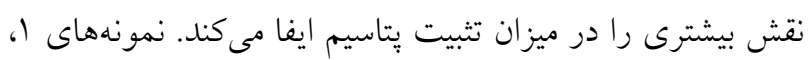

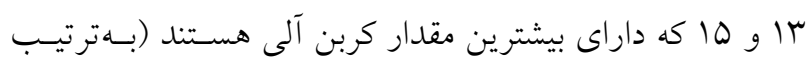

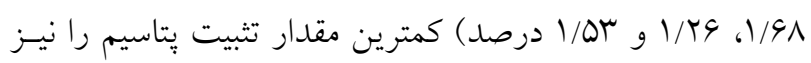

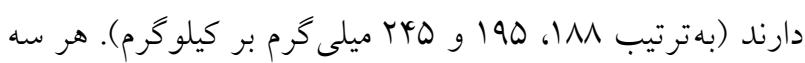
نمونه، افقهاى سطحى (Ap) خاكرخ هاى مطالعه شده هستـند. افقهاى سطحى بيشتر در معرض عوامل محيطى بوده و تجزيـهـ

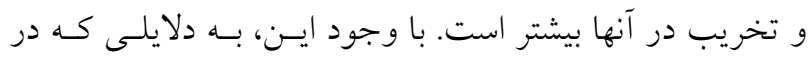

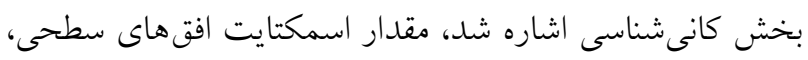

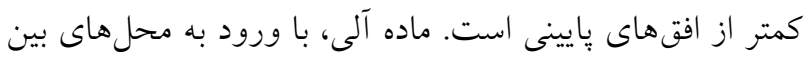


تبادل كاتيونى با ميزان تثبيت، اين نتايج قابـل بـيشبينس اسـت.

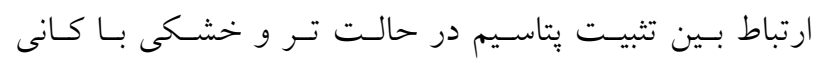
اسمكتايت در شكل (r) آورده شده است. از آنجايى كه واكسنش

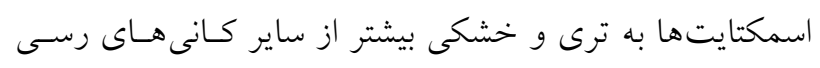

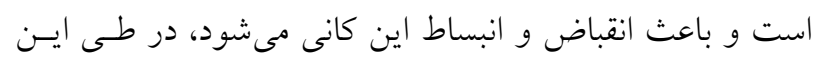

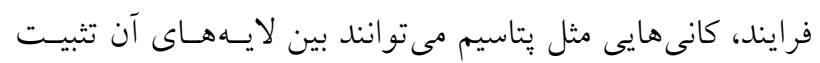

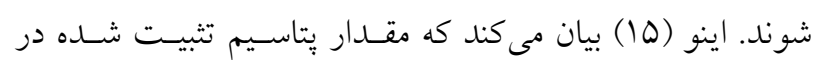

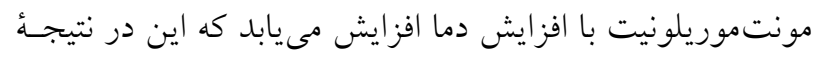

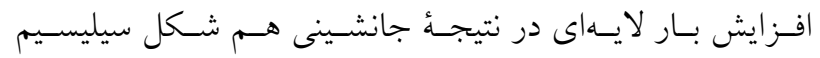

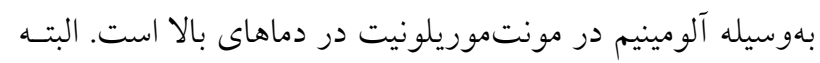

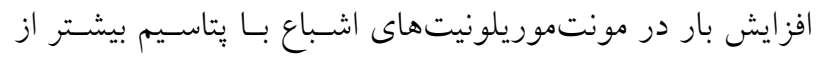

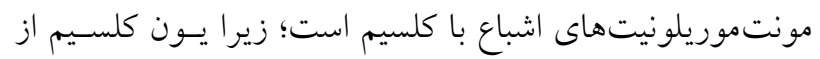

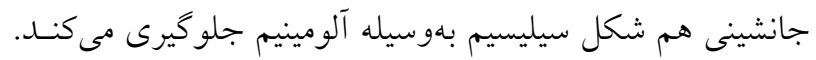

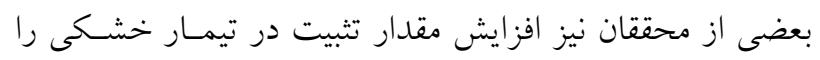

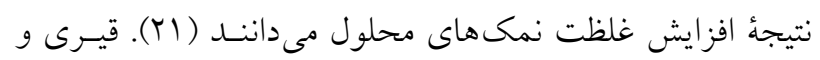

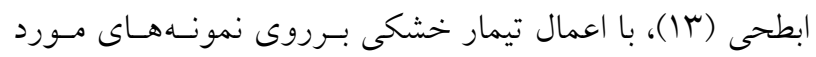

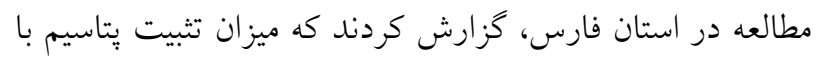

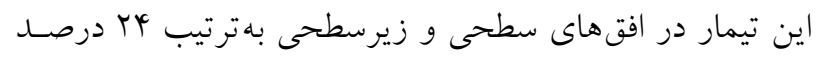

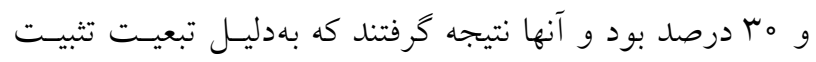

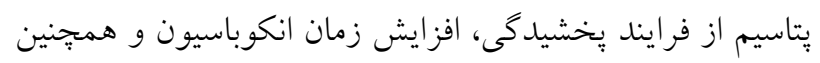

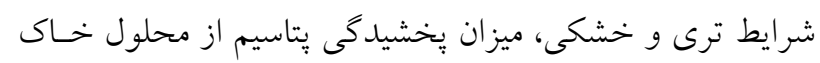

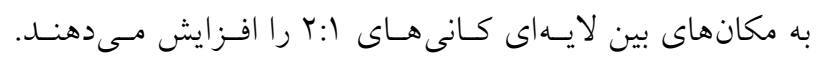

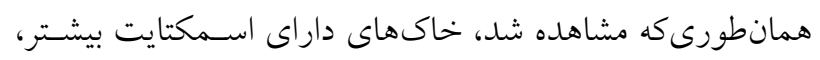

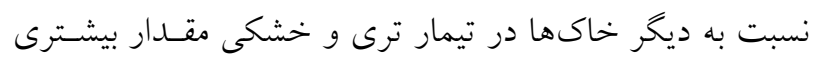

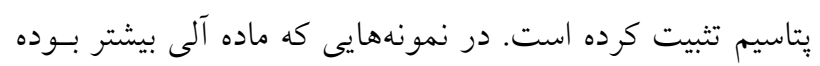

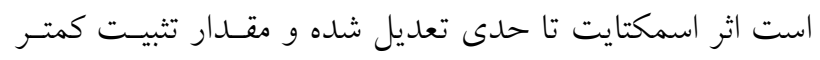
شده است.

\section{نتيجه گيرى}

نتايج نشان داد كه كانى اسمكتيت مهم ترين و فراوانترين كسانى خاكهاى منطقه است. منطقه مورد مطالعه داراى بارنــــى زئى زيـاد

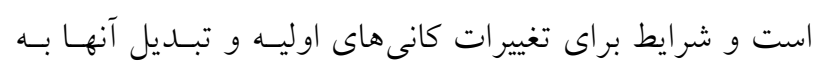

كاهش ظرفيت تثبيت بِّاسيم شده است مسى توانـد واكـنش بـين

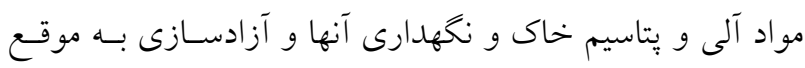

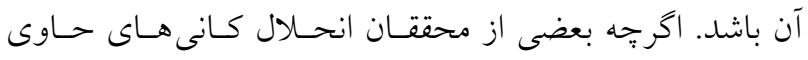

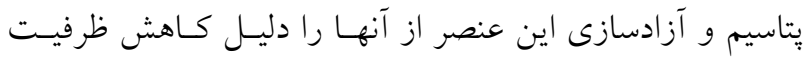

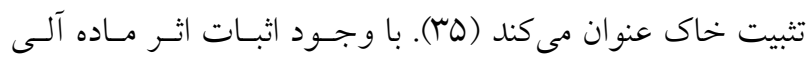

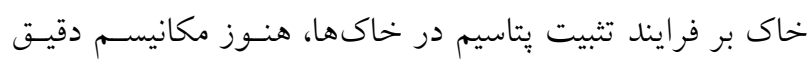

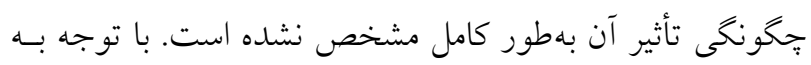

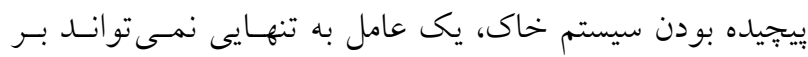

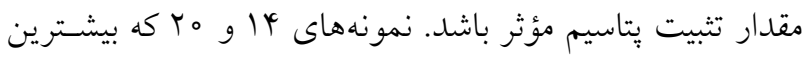

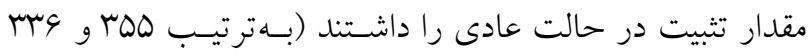

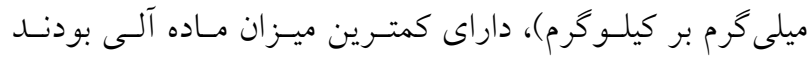

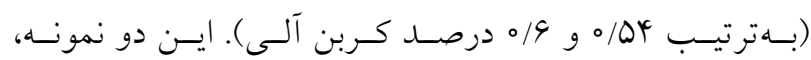
نمونههاى عمقى بوده كه كمتر تحت شرايط محيطى قرار گرفتسه

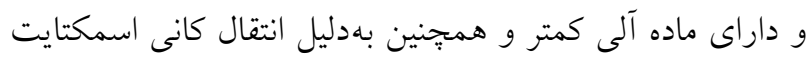
از افقهاى بالايى داراى اسمكتايت زيادترى نسبت به افـقهـاى بالايى هستند.

ترى و خشكى متناوب از عوامل مؤثر بر تثبيـت بِّاسـيم در

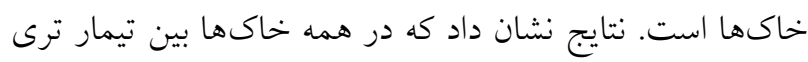
و خشكى و تثبيت يتاسيم اختلاف معنى دارى وجود دارد (شكل

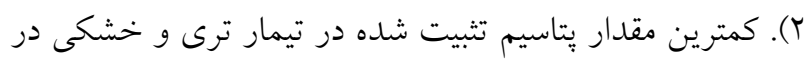

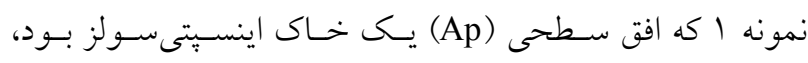

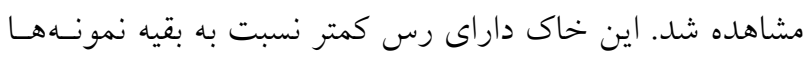

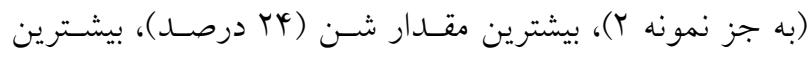

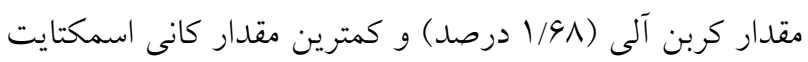

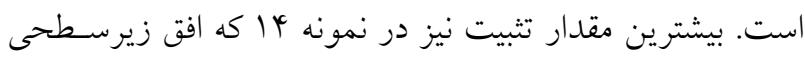

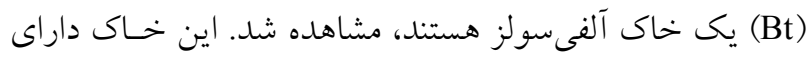
بيشترين مقدار رس (9N درصد)، كمترين مقدار شن (أ درصد)،

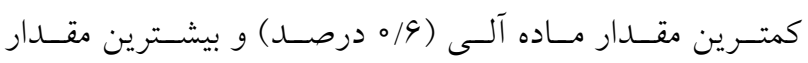

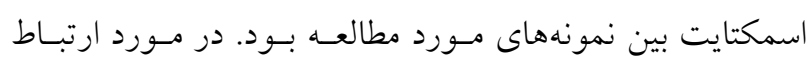

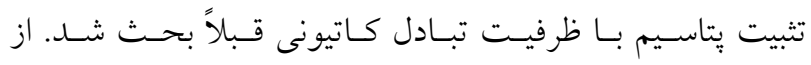

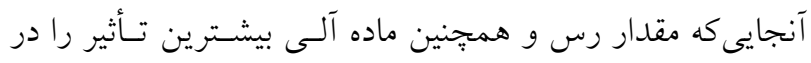

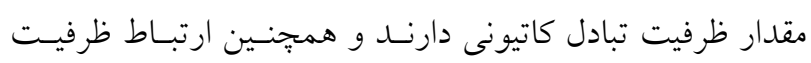


كانى هايى مانند اسمكتايت كافى بهنظر مىرسد. با افزايش سطح قوىتر است. در مورد اينكه آيا فرايند تثبيت پِّاسيم قيديدهاى مفيد و يا مضر

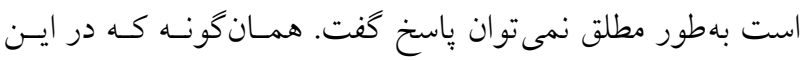
تحقيق مشاهده شد، مقدار تثبيت در خاكهـاى سطحى كمتــر از

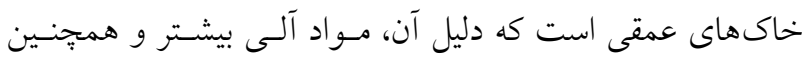

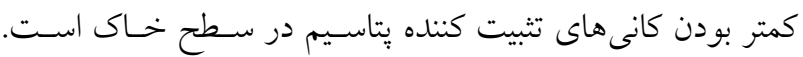

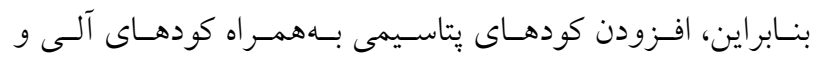
همجنين كود دهى در لايه سطحى خاك براى جلو گيرى از تثبيت

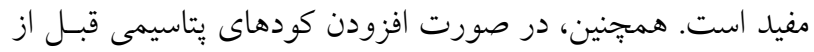
كشت، بايد تا حد امكـان از تـر و خشـك شـــن متنـاوب زمسين

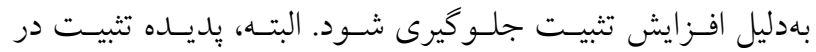

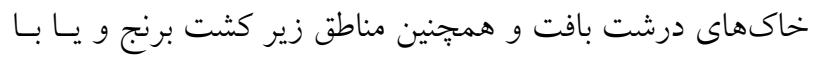
بارندگى زياد، بهدليل جلوكيرى از هدر رفـت يتاسـيم افـزوده بـهـ خاك، بِديدهاى مفيد محسوب مى شود. همجينين، از آنجايى كه در بهر بسيارى از زمينهاى كشاورزى كشور، در طـول سـاليان كذشـته،

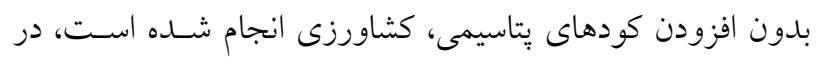

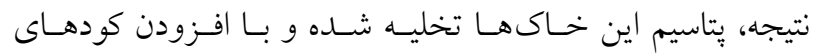

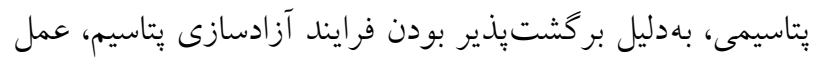

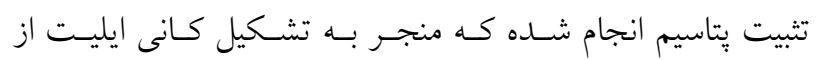

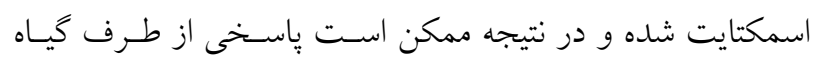
نسبت به افزودن اين كودها داده نشود.

\section{سباسكزارى}

اين يزوهش بخشى از طرح تحقيقاتى در قالب يُزوهانه (شـماره 

نور تأمين شده است و بدينوسيله تشكر و قدردانى مىشود. يتاسيم افزوده شده به خاك، مقدار تثبيت افزايش، ولى درصـا

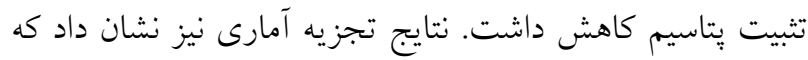

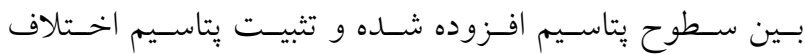
معنى

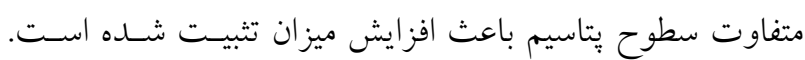

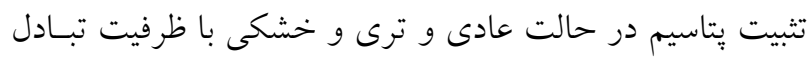

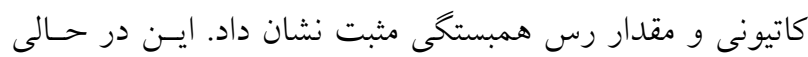

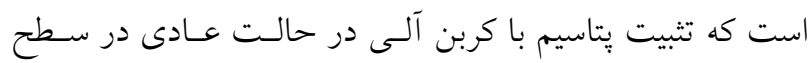
يكى درصد و در حالت تـرى و خشكى در سطح :-نسج درصـد

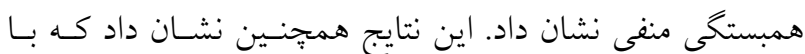

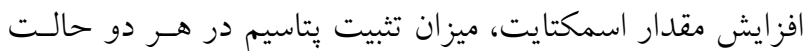
عادى و ترى و خشـكى افـزايش مسى يابـــ. همجنــين افـقهـاى سطحى، بهدليل داشتن ماده آلى بيشتر و اسمكتايت كمتر، مقــدار

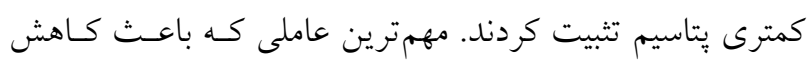

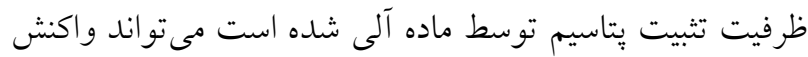

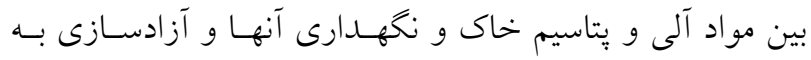
موقع آن باشد. بعضى از يزوهشخران ارتباط قوى و بعضى ديخر

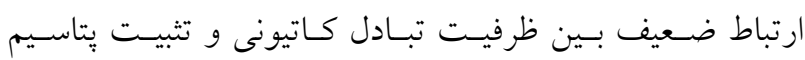

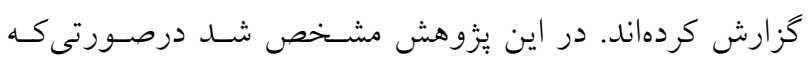

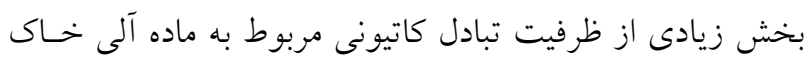

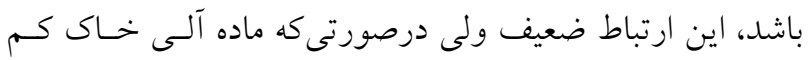

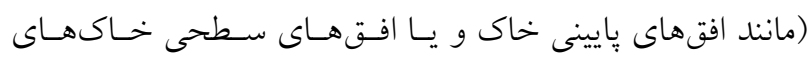

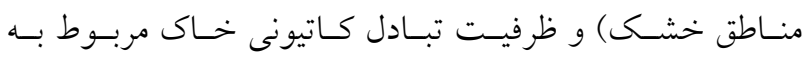

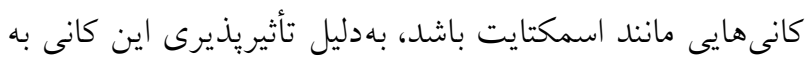

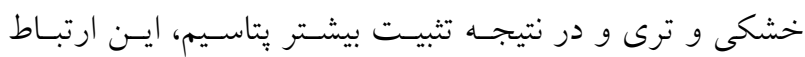

\section{منابع مورد استفاده} ا. بستانى، ع. و غ. ثواقبى فيروزآبادى. هوسا. بررسى ظرفيت تثبيت يتاسيم در تعدادى از خاك هاى زير كشت نيشكر خوزستان، نشريه

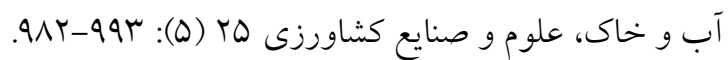

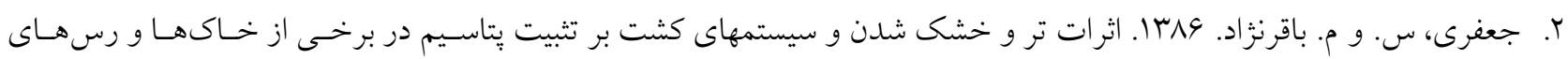

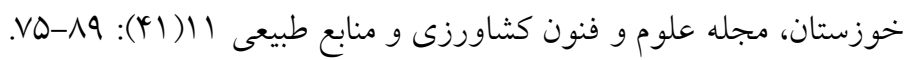




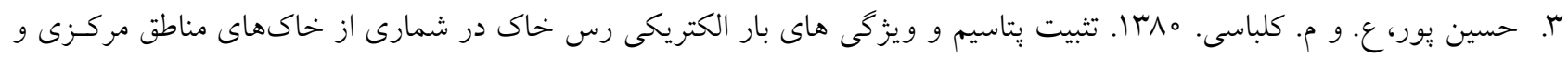

$$
\text { شمال ايران، مجله علوم و فنون كشاورزى و منابع طبيعى ه (r)): }
$$

4. Arnold, P. W. and B. M. Close. 1961. Potassium-releasing power of soils from the Agdell rotation experiment assessed by glasshouse cropping. J. Agric. Sci. 57(3): 381-386.

5. Barshad, I. and F. M. Kishk. 1970. Factors affecting potassium fixation and cation exchange capacities of soil vermiculite clays. Clays Clay Miner. 18: 127-137.

6. Bouabid, R., M. Badraoui and P. R. Bloom. 1991. Potassium fixation and charge characteristics of soil clays. Soil Sci. Soc. Am. J. 55(5): 1493-1498.

7. Bouyoucos, C. J. 1962. Hydrometer method for making particle-size analysis of soils. Agron. J. 57: 464-465.

8. Brady, N. C. and R. R. Weil. 2008. The nature and properties of soils (No. Ed. 15), Prentice-Hall Inc. Washington.

9. Chittamart, N., A. Suddhiprakarn, I. Kheoruenromne and R. J. Gilkes. 2010. Charge properties and potassium fixation by clay from Thai Vertisols. In: Proceedings of the $19^{\text {th }}$ World Congress of Soil Science: Soil Solutions for A Changing World, Brisbane, Australia. PP. 26-29.

10. Dhaliwal, A. K., R. K. Gupta, Y. Singh and B. Singh. 2006. Potassium fixation and release characteristics of some benchmark soil series under rice-wheat cropping system in the Indo-Gangetic plains of northwestern India. Commun. Soil Sci. Plant Anal. 37: 827-845.

11. Dixon, J. B. and S. B. Weed. 1992. Minerals in soil environments. 2nd Edition. SSSA. Madison, Wisconsin, U.S.A.

12. Dyer, B. 1894. XV.-On the analytical determination of probably available "mineral" plant food in soils. J. Chem. Soc. Trans. 65: 115-167.

13. Ghiri, M. N. and A. Abtahi. 2012. Factors affecting potassium fixation in calcareous soils of southern Iran. Arch. Agron. Soil Sci. 58(3): 335-352.

14. Grim, R. E. 1968. Clay mineralogy. International Series in the Earth and Planetary Sciences. McGraw-Hill, New York.

15. Inoue, A. 1983. Potassium fixation by clay minerals during hydrothermal treatment. Clays Clay Miner. 31: 81-91.

16. Jackson, M. L. 1975. Soil Chemmical Analysis Advanced Course. Department of Soils, College of Agriculture, University of Wisconsin, Madison.

17. Khormali, F. and A. Abtahi. 2003. Origin and distribution of clay minerals in calcareous arid and semiarid soils of Fars province, southern Iran. Clay Miner. 38: 511-527.

18. Kittrick J. A. and E. W. Hope. 1963. A procedure for the particle size separation of soils for X-ray diffraction Analysis. Soil Sci. 96: 312-325.

19. Loeppert, R. H. and D. L. Suarez. 1996. Carbonate and gypsum, PP: 437-474. In: D. L. Sparks (Ed.) Methods of Soil Analysis, SSSA Book Series, Part 3, Madison, WI.

20. Malavolta, E. 1985. Potassium status of tropical and subtropical region soils. pp. 163-200. In: R. D. Munson (Ed.). Potassium in Agriculture. American. Society. of Agronomy, Madison, WI.

21. Martin, J. C., R. Overstreet and D. R. Hoagland. 1945. Potassium fixation in soils in replaceable and nonreplaceable forms in relation to chemical reactions in the soil. Soil Sci. Soc. Am J. 10:94-101.

22. Mc Lean, E. O. and M. E. Watson. 1985. Soil measurements of plant-available potassium. Potassium in agriculture, (Potassiuminagri) 277-308.

23. Mehra, O. P. and M. L. Jackson. 1960. Iron oxide removal from soils and clays by a dithionate citrate system with sodium bicarbonate. Clay Miner. 7: 317-327.

24. Mortland, M. M. 1986. Mechanism of adsorption on nonhumic organic species by clays. pp. 59-76. In: P. M. Huans and M. Schnitzer (Eds.), Interaction of Soil Minerals with Natural Organics and Microbes. SSSA Spec. Publ. 17. SSSA, Madison, WI.

25. Nelson, D. W. and L. Sommers. 1982. Total Carbon, Organic Carbon and Organic Matter. Methods of Soil Analysis. Part 2. Chemical and Microbiological Properties, (Methodsofsoilan2), 539-579.

26. Olk, D. C., K. G. Cassman and R. M. Carlson. 1995. Kinetics of potassium fixation in vermiculite soils under different moisture regimes. Soil Sci. Soc. Am. J. 59: 423-429.

27. Owliaie, H. R., A. Abtahi and R. J. Heck. 2006. Pedogenesis and clay mineralogical investigation of soils formed on gypsiferous and calcareous materials, on a transect, southwestern Iran. Geoderma. 134: 62-81.

28. Pohlman, A. A. and J. G. Mc Coll. 1986. Kinetics of metal dissolution from forest soils by soluble organic acids. J. Environ. Qual 15(1): 86-92.

29. Pratt, P. F. 1965. Potassium. pp. 1022-1030. In: C. A. Black. Methods of Soil Analysis, part 2. American Society of Agronomy, Madison, WI.

30. Rees, G. L., G. S. Pettygrove and R. J. Southard. .2013. Estimating plant-available potassium in potassium-fixing soils. Commun. Soil Sci. Plant Anal. 44(1-4): 741-748. 
31. Reid-Soukup, D. A. and A. L. Ulery. 2002. Smectites. pp. 467-499. In: J. B. Dixon and D. G. Schulze (Ed.). Soil Mineralogy with Environmental Application, SSSA, Inc., Madison, WI, USA.

32. Simonsson, M., S. Hillier and I. Öborn. 2009. Changes in clay minerals and potassium fixation capacity as a result of release and fixation of potassium in long-term field experiments. Geoderma 151(3): 109-120.

33. Sparks, D. L. 2000. Bioavailability of soil potassium. PP: 301-319. In: M. E. Sumner (Ed.), Handbook of Soil Science, CRC Press, Boca Raton, FL.

34. Sumner, M. E., W. P. Miller, D. L. Sparks, A. L. Page, P. A. Helmke, R. H. Loeppert and C. T. Johnston. 1996. Cation exchange capacity and exchange coefficients. Methods of soil analysis. Part 3-chemical methods. University of Georgia, Athens, Georgia. 1201-1229.

35. Tan, K. H. 1980. The release of silicon, aluminum, and potassium during decomposition of soil minerals by humic acid. Soil Sci. 129: 5-11.

36. Troeh, F. R. and L. M. Thompson. 2005. Soils and Soil Fertility. Iowa, Blackwell.

37. Volk, N. J. 1934. The fixation of potash in difficultly available form in soils. Soil Sci. 37(4): $267-288$. 


\title{
Potassium Fixation and its Relationship with Physico-Chemical Properties and Clay Minerals in the Calcareous Soils of Kakan Plain, Kohgilouye \& Boyerahmad Province
}

\author{
S. Shakeri ${ }^{1^{*}}$
}

(Received: Aug. 25-2016; Accepted: March. 7-2017)

\begin{abstract}
Potassium fixation is one of the most important factors influencing the availability of this ion for plants. This research was carried out to evaluate the relationship between potassium (K) fixation with some physical and chemical characteristics of soils and clay minerals and to investigate the effect of the dry and wet cycle on potassium fixation in Kakan Plain, in Kohgilouye \& Boyerahmad Province. To measure the amount of Potassium fixation, four levels of K were added to the samples and the samples were shaken for $24 \mathrm{~h}$ and then dried in the oven at $50^{\circ} \mathrm{C}$ for $24 \mathrm{~h}$. The drying and wetting cycle was repeated three times. Another set of soil samples was similarly incubated for a period similar to the previous treatment, but drying was performed at room temperature in an equilibrium state. The results showed that potassium fixation was increased with the potassium concentration increment, whereas $\mathrm{K}$ fixation percentage was reduced. Also, potassium fixation showed a positive significant relationship with cation exchange capacity (CEC) as well as clay content, in both normal and dry and wet treatments, and a negative significant relationship with organic carbon. Moreover, potassium fixation was enhanced with the increase of smectite content in both normal and dry and wet treatments. Besides, due to more organic carbon and less smectite, surface horizons fixed K less than the subsurface horizons.
\end{abstract}

Keywords: Smectite, Potassium fixation, Drying and wetting, Organic carbon, Kakan plain.

1. Dept. of Agric., Payame Noor Univ., Tehran, Iran.

*: Corresponding Author, Email: shakeri@pnu.ac.ir 